\title{
Effect of compressed propane extraction on storage stability of dried cilantro
} (Coriandrum sativum $\mathbf{L}$.)

Abbreviated Title: Effect of propane extraction on storage stability of dried cilantro Jasreen K Sekhon $^{1 *}$, Niels O Maness ${ }^{2}$, Carol L Jones ${ }^{1}$

${ }^{1}$ Department of Biosystems and Agricultural Engineering, College of Engineering, Architecture and Technology, Oklahoma State University, Stillwater, OK 74078

${ }^{2}$ Department of Horticulture and Landscape Architecture, College of Agricultural Sciences and Natural Resources, Oklahoma State University, Stillwater, OK 74078

*Corresponding author. 101 Ag Hall, Stillwater OK 74078. Email: jasreen@okstate.edu (Jasreen Sekhon), Phone: (814) 777-2084. Present address: 1567 Food Science Building, Ames IA 50011. 


\section{Abstract}

48 Compressed solvents have been used to extract oils from food materials for use in

49 the food industry. Raffinate, residue left after solvent extraction, may be utilized as a

50 food adjunct. We investigated the effect of compressed propane extraction on the stability

51 of color and volatile composition in cilantro during prolonged storage. Dried cilantro was

52 extracted with compressed propane $\left(21-27^{\circ} \mathrm{C}\right)$ and stored (freezer, refrigerator, room

53 temperature and elevated temperature) for up to 12 months. At 30-day intervals, the

54 samples were tested for change in color $\left(\mathrm{L}^{*}, \mathrm{a}^{*}, \mathrm{~b}^{*}\right.$, chroma, hue angle and browning

55 index BI) and volatile composition. Green color and volatile compounds were best

56 preserved when cilantro samples were dried at $60^{\circ} \mathrm{C}$, extracted with propane, and stored

57 in refrigerator or in freezer. It was concluded that preprocessing conditions and storage

58 conditions govern the degree of loss in color and volatile composition of cilantro during

59 prolonged storage.

60 Keywords: solvent extraction with compressed propane, dehydration, storage, cilantro,

61 color, volatile composition

62

63 


\section{Introduction}

Herbs and spices such as cilantro are food adjuncts that enhance sensory quality and provide nutritional and medicinal value to food products (Srinivasan, 2005).

Quality characteristics of fresh cilantro are appearance, leaf size, form, color, aroma and flavor. Color and aroma are important sensory attributes that govern acceptance of a product by the consumer. Volatile compounds in fresh cilantro have been reported in literature (Fan and Sokorai, 2002, Mookherjee et al., 1989, Potter and Fagerson, 1990, Potter, 1996). Major volatile compounds in cilantro are aldehydes $(82.6 \%)$ followed by alcohols (16.6\%) (Potter \& Fagerson, 1990). Higher temperature drying $\left(60^{\circ} \mathrm{C}\right)$ has been reported to retain better color quality and higher concentration of volatile compounds in cilantro compared to lower temperature $\left(40^{\circ} \mathrm{C}\right)$ drying (Sekhon et. al, 2015). However, no study till date has reported the effect of prolonged storage on color and volatile composition of dried cilantro.

Alternative extraction solvents such as supercritical carbon dioxide and compressed gases (propane and butane) have been studied extensively for oil extraction (Sparks, 2006). Several commercial processes have successfully used compressed propane as a solvent for extraction of oil from soybean, rice bran, cardamom, coriander seeds, grape seed, etc. (Hamdana et al., 2008, Sparks, 2006, Freitas et al., 2008, Illes et al., 2000). The extract (or oil) from natural herbs is rich in antioxidants and is used in the food industry (Babovic et al., 2010). Raffinate, the residue left after solvent extraction, may also be utilized as a food adjunct or as a condiment in the food industry. However, to the best of our knowledge no work has reported such utilization of raffinates from solvent extraction of herbs. Therefore, present work investigated the effect of propane extraction on the storage quality (color and volatile composition) of dried cilantro samples. Propane is a gas under ambient 
conditions and liquid at $\leq-43^{\circ} \mathrm{C}$ and atmospheric pressure. It is GRAS (generally recognized as safe) and leaves no residue, but is flammable and requires extraction to be performed in explosion-proof facility. Sekhon et al. (2015) reported no negative effect of compressed propane extraction on the quality of dried cilantro.

$$
\text { Dehydrated herbs such as cilantro have retail shelf life of } 1 \text { - } 2 \text { years. Previous }
$$

studies have reported change in characteristic color of dehydrated herbs during storage (amaranth leaves, Negi and Roy, 2001; French tarragon, Arabhosseini et al., 2007; basil, Paakkonen et al., 1990; curry leaves, Singh and Sagar, 2010). Stability of volatiles in dried herbs can be affected by type of the plant material, drying process (method and temperature), packaging material and/or storage conditions (tarragon, Arabhosseini et al., 2007; cumin powder, Bera et al., 2001; basil, Baritaux et al., 2006; rosemary leaves, Diaz-Maroto et al., 2009; rosemary and thyme, Usai et al., 2011; thyme, Rowshana et al., 2013).

No study till date has evaluated the effect of compressed propane extraction and prolonged storage on the stability of color and volatile composition in cilantro.

Therefore, objectives of the study were (1) to determine the effect of storage temperature and storage time on color and volatile composition of pre-processed (dried and size reduced) cilantro and (2) to determine the effect of propane extraction on storage quality (color and volatile composition) of dried cilantro.

\section{Materials and methods}

\subsection{Chemicals}

Solvent n-hexane was purchased from Fisher Scientific (Fair Lawn, New Jersey, US). $\beta$-pinene, decanal, decanol, diallyl fumerate, E-2-dodecenal, tridecanal, E-2tridecenal, undecanal, dodecanal, E-2-undecenal, linalool, nonane, nonanal, E-2decenol, E-9-decenol, octanal and E-2-nonenal were purchased from Sigma-Aldrich 
114 (Sigma-Aldrich Co. LLC., St. Louis, Missouri). E-9-decenal was purchased from

115 Bedoukian (Bedoukian Research, Inc., Danbury, Connecticut). $\beta$-myrcene, dodecanol

116 and E-2-dodecenol were purchased from Fluka (Sigma-Aldrich GmbH, Seelze,

117 Germany). Tetradecanal and E-2-tetradecenal were purchased from Penta (Penta

118 manufacturing company LLC, Livingston, New Jersey).

119 2.2. Preparation of cilantro for storage

120 Cilantro was harvested from field plots at the Oklahoma Vegetable Research

121 Station at Bixby, Oklahoma and transported on ice to laboratory facilities at

122 Oklahoma State University, Stillwater, OK. Samples were dried at $40^{\circ} \mathrm{C}$ or $60^{\circ} \mathrm{C}$, size

123 reduced and fractionated into large flakes (LF), small flakes (SF) and coarse powder

$124(\mathrm{CP})$ using a kitchen strainer (sieve size $3.3 \mathrm{mmx} 3.03 \mathrm{~mm}$, pore density $0.3 / \mathrm{mm}^{2}$ ) and

125 a round splatter screen (sieve size $1.78 \mathrm{~mm} \times 1.53 \mathrm{~mm}$, pore density $0.57 / \mathrm{mm}^{2}$ )

126 according to Sekhon et al. (2015). The particle sizes of each fraction were estimated

127 using RO-TAP sieve shaker to be LF: $0.85-1.18 \mathrm{~mm}$, SF: $0.71-1.0 \mathrm{~mm}$ and CP:

$1280.25-0.5 \mathrm{~mm}$. Dried and size reduced cilantro samples were then extracted using a

129 5L propane extractor (Hy-Look RV-2 Series; Eden labs, Columbus, OH) according to

130 Sekhon et al. (2015). The extractor consisted of a propane storage tank, an extraction

131 vessel, two separation vessels (I \& II), and a compressor. Compressed propane

132 (AirGas, Radnor, PA) was used as an extraction solvent at flow rate of $0.64 \mathrm{lpm}$, with

133 extractor temperature and pressure maintained at $21-27^{\circ} \mathrm{C}$ and $1.1-1.9 \mathrm{MPa}$,

134 respectively and separation vessel I temperature at $\leq 38^{\circ} \mathrm{C}$. Propane dissolved non

135 polar compounds from dried cilantro and carried them into the separation vessel I.

136 Once extraction was complete, propane was vaporized and recondensed by the

137 compressor into the propane storage tank. The extract and raffinate were then

138 recovered. 


\subsection{Storage}

Samples were stored in refrigerator $\left(4.9^{\circ} \mathrm{C} \pm 0.56\right)$, at room temperature $\left(23.3^{\circ} \mathrm{C} \pm\right.$ $2.91 ; \mathrm{RH} 46.84 \% \pm 10.86)$, at elevated temperature $\left(37.83^{\circ} \mathrm{C} \pm 4.12 ; \mathrm{RH} 70.45 \% \pm\right.$ $18.87)$, and in freezer $\left(-20^{\circ} \mathrm{C}\right)$. Samples stored in refrigerator, at room temperature or at elevated temperature (in an environment chamber-Parameter Generation \& Control Inc., Black Mountain, NC) were packaged in Al foil bags. Samples stored in freezer were packaged in brown glass bottles (with plastic caps); this treatment was used as a control to compare other storage conditions against it.

Each $0.1397 \mathrm{~m}$ x $0.1778 \mathrm{~m}$ (5.5 in x 7 in; O.D) Al foil laminate bag (4.3 mil; Impak Corporation, Los Angeles, CA) was heat sealable with an open zipper end. Bags were made of four layers: polyethylene terephthalate (PET), polyethylene (PE), Al foil and linear low density polyethylene (LLDPE). PET provides strength to the package and is printable, $\mathrm{Al}$ foil acts as a barrier to water vapors and gases and is noncorrosive, and LLDPE and PE facilitate heat sealing of the package. Water vapor transmission rate and oxygen transmission rate of the package as provided by the manufacturer were $<5 \times 10^{-6} \mathrm{~kg} / 0.0645 \mathrm{~m}^{2} .24 \mathrm{~h}$ and $1 \times 10^{3} \mathrm{~m}^{3} / \mathrm{m}^{2} / 24 \mathrm{~h}$, respectively. For each storage temperature, twelve sets (one for each month) of twenty four samples $(2$ drying temperatures $\times 3$ particle sizes $\times 4$ extraction durations $=24$ samples) were packaged in at least duplicates. Filled bags were evacuated from ambient pressure to $<0.3 \mathrm{kPa}$, back flushed with a standard air mixture of $21 \%$ oxygen in nitrogen (Airgas, Stillwater, OK) for $15 \mathrm{sec}$ and heat sealed in a MultivacA316 vacuum packaging machine (Multivac, Inc., Kansas City, MO). The packages were then placed in storage. On day 0 and at 30-day intervals thereafter, samples were taken out and analyzed for moisture content, color values and volatile composition. 


\subsection{Sample analyses}

Moisture content of samples was measured in a forced air oven at $70^{\circ} \mathrm{C}$ to constant weight. Color and volatile composition of samples were evaluated according to Sekhon et al. (2015). Briefly, color (CIE L*, a*, b*) of dried cilantro samples was measured using a Minolta chroma meter CR-300 (Minolta Inc., Osaka, Japan). L*, a*, $\mathrm{b}^{*}$ values were measured by taking 15 random samples (approximately $1 \mathrm{~g}$ ) from the package. Chroma, hue angle, and BI were then calculated using equations 1 - 4.

$$
\begin{aligned}
& \text { Chroma }=\sqrt[2]{\left(a^{* 2}+b^{* 2}\right)} \quad 1 \text { Hue angle }=180+\tan ^{-1}\left(\frac{b^{*}}{a^{*}}\right) \\
& \mathrm{x}=\frac{\left(\mathrm{a}^{*}+1.75 \mathrm{~L}^{*}\right)}{\left(5.645 \mathrm{~L}^{*}+\mathrm{a}-3.012 \mathrm{~b}^{*}\right)} \quad 3 \mathrm{BI}=\frac{100(\mathrm{x}-0.31)}{0.17}
\end{aligned}
$$

Volatile compounds in samples were quantified by extracting representative sample (5 - $6 \mathrm{~g})$ with $\mathrm{n}$-hexane $(4 \mathrm{~mL})$. The extract obtained after extraction was concentrated under a stream of nitrogen to $1 \mathrm{~mL}$. $\beta$-pinene $(100 \mathrm{nmol})$ and $\beta$-myrcene $(50 \mathrm{nmol})$ were used as internal and analytical standard respectively. One $\mu \mathrm{l}$ of the concentrated extract (containing analytical standard $\beta$-myrcene; $50 \mathrm{nmol}$ ) was injected on to DB-5 fused silica capillary column (30 m x $0.25 \mathrm{~mm}$ x $0.25 \mu \mathrm{m}$ film thickness; $\mathrm{J}$ and W Scientific Inc., Rancho Cardova, CA) in a gas chromatograph (GC; Varian Star 3400 Cx, Varian Inc., 2700 Mitchell Drive, Walnut Creek, CA 94598). GC used helium as carrier gas with a linear flow rate of $20 \mathrm{~cm} / \mathrm{sec}$ and FID detector. Peaks were identified by co-elution with authentic standards and quantified relative to the analytical internal standard, $\beta$-myrcene using equation 5 . 


\subsection{Statistical analysis} Model) was performed in SAS (SAS Inc., Cary, NC, ver. 9.3). Least square means of response variables and multi-comparison tests for the effect stemp $\times$ stime were performed. The response variables were color values and concentration $(\mu \mathrm{g} / \mathrm{g})$ of volatile compounds in the cilantro samples.

194

\section{Results}

Dehydrated herbs such as cilantro are sold as shelf-stable commodities in the form of powder or flakes with a shelf life of 1 - 2 years. The results from this study provide insights into the optimum preprocessing and storage conditions that can be used to prolong shelf life of dried cilantro. In addition, this study has shown a possibility for utilization of raffinates after extraction of herbs using compressed solvents such as propane.

\subsection{Moisture content}

Moisture contents of cilantro samples at the start and the end of storage are listed in Table S1 (Supporting document). A considerable change in moisture content of stored samples was not observed. This was expected because of low water vapor transmission rate of $\mathrm{Al}$ foil laminate packages $\left(<5 \times 10^{-6} \mathrm{~kg} / 0.0645 \mathrm{~m}^{2} .24 \mathrm{~h}\right)$.

\subsection{Color}

\subsubsection{Effect of storage temperature}

Prolonged storage of cilantro samples (dried and/or propane extracted) resulted in a significant decrease in $-\mathrm{a}^{*}$ values (greenness) and increase in BI values (brown color). This change in color was prominent in samples stored at room temperature or at elevated temperature. In addition, a significant decrease in $\mathrm{L}^{*}$ values (Lightness) 
was also observed in samples stored at elevated temperature (Table S2 - Table S7,

213 supporting information). Figure 1a shows the change in $-\mathrm{a}^{*}$ values of $\mathrm{CP}$ when stored

214 in freezer, in refrigerator, at room temperature or at elevated temperature for 12

215 months. Irrespective of the preprocessing conditions (dehydration temperature) a

216 gradual decrease in $-\mathrm{a}^{*}$ values of samples stored at room temperature and a drastic

217 decrease in $-a^{*}$ values of samples stored at elevated temperature was observed with

218 increase in storage time. Further, storage at elevated temperature resulted in a

219 significant increase in BI values of all cilantro samples (Figure 1b). Storage in the

220 freezer or in the refrigerator were found to be the best storage treatments to maximize

221 retention of green color (highest $-\mathrm{a}^{*}$ value) and minimize browning (lowest BI

222 values) in cilantro samples. This indicated that during prolonged storage ( 12 months)

223 freezer and refrigerator storage temperature preserve better color quality of dried

224 cilantro compared to current room temperature storage of packaged dried herbs in the

225 retail market.

226 The decrease in $-\mathrm{a}^{*}$ values (greenness) during storage could be due to the loss of 227 chlorophyll to pheophytin (Steet and Tong, 1996). This decrease was greater in 228 samples preprocessed at $40^{\circ} \mathrm{C}$ (lower $-\mathrm{a}^{*}$ values and higher $\mathrm{BI}$ ) compared to samples 229 dried at $60^{\circ} \mathrm{C}$ (higher $-\mathrm{a}^{*}$ values and lower BI values). The loss of chlorophyll in 230 dehydrated products is also accompanied by non-enzymatic browning (Negi and Roy, 231 2001). Therefore, an increase in BI values during storage can be correlated with a 232 decrease in $-\mathrm{a}^{*}$ values and non-enzymatic browning. Accelerated aging of cilantro 233 samples stored at elevated temperature $\left(40^{\circ} \mathrm{C}, \mathrm{RH} 70 \pm 18 \%\right)$ was evident by loss of $234 \mathrm{a}^{*}$ values and increase in BI values. An increase in BI values in samples stored at elevated temperature could also be due to higher storage temperature and higher 
concluded that stability of color values in cilantro samples during storage was dependent on drying temperature and storage temperature.

\subsubsection{Effect of propane extraction}

Compressed propane extraction did not negatively affect the color of cilantro samples during storage. At any given time during storage, $-\mathrm{a}^{*}$ values of extracted samples (10 min) were greater than $-a^{*}$ values of unextracted samples (Figure $2 a$ ). was comparable: decrease in $-\mathrm{a}^{*}$ values with increase in storage temperature.

Figure $2 \mathrm{~b}$ shows the effect of storage on BI values of extracted (10 min) and unextracted CP samples. At any given time during storage, BI values of unextracted samples were higher than extracted samples indicating greater brown pigment in unextracted samples than in extracted samples. Further, the BI values of cilantro samples were dependent on drying temperature and storage temperature. Extracted samples stored at elevated temperature $\left(40^{\circ} \mathrm{C}\right)$ exhibited a linear increase in $\mathrm{BI}$ values 252 in the first five months, after which it became almost constant. On the other hand, no 253 significant change in BI values of extracted samples stored in the freezer was observed. As observed for unextracted samples, BI values of extracted samples (LF, SF and CP; Table S2 - Table S7, supporting information) derived from cilantro dried

256 at lower temperature were higher compared to samples derived from cilantro dried at

257 higher temperature. This difference in BI values, of samples dried at two temperatures, was more pronounced in accelerated storage (elevated temperature)

259 compared to other storage conditions (freezer, refrigerator or room temperature). This

260 difference in BI values could be attributed to loss of chlorophyll and non-enzymatic 261 browning at lower temperature drying compared to higher temperature drying. These 
results indicate that change in color values in extracted samples followed the same trend as the unextracted samples, however compressed propane extraction resulted in improving color stability of dried cilantro during prolonged storage. Volatile Composition storage (in refrigerator or in freezer), the concentration of all volatile compounds in all samples decreased with increase in storage time. This was expected because evaporation of volatile compounds is a continuous process. The rate of evaporation can be reduced but volatile loss cannot be prevented. Baritaux et al. (2006) found

271 similar results for drying and storage of basil. Volatile compounds evaluated in this study were: Major volatile compounds (concentration $>40 \mu \mathrm{g} / \mathrm{g}$ dried cilantro): E-2tetradecenal, dodecanal, E-2-dodecenal, and tetradecanal; Intermediate compounds (4 $\mu \mathrm{g} / \mathrm{g}$ to $40 \mu \mathrm{g} / \mathrm{g})$ : decanal, nonane, octanal, decanol, tridecanal, E-2-tridecenal, E-2dodecenol, dodecanol, and undeca- nal; and Minor compounds (concentration $<4$ $\mu \mathrm{g} / \mathrm{g}$ dried cilantro): linalool, nonanal, E-2-undecenal, 9-decenal, E-2-nonenal, phenyl- acetaldehyde, and E-2-decenal (Table 1).

\subsubsection{Effect of storage temperature on volatile composition}

The concentration of all volatile compounds, except nonane, in cilantro samples (dried and/or propane extracted) decreased with increase in storage time (Table 1 and

281 Table 2). Regardless of drying temperature and sample particle size, the decrease in the concentration of major volatile compounds was least in samples stored in the freezer (68 - 97\%) followed by those stored in the refrigerator $(77-98 \%)$, at room temperature (94 - 99\%) and at elevated temperature ( $\geq 99 \%)$. Among all volatile compounds, maximum decrease in concentration was observed in tetradecanal, undecanal, E-2-tridecenal, dodecanal and decanal. This decrease was least in samples 
stored in the freezer or in the refrigerator compared to samples stored at room temperature or at elevated temperature. Overall, the four storage conditions may be divided into two storage temperature groups, one group that preserved aromatic volatile compounds (storage in freezer or in refrigerator) and second group that led to

291 least retention of aromatic volatile compounds (storage at room temperature or at 292 elevated temperature).

The rate of volatile loss was maximum in the first two months of storage, the loss

294 being greater in samples dried at higher temperature compared to samples dried at

295 lower temperature (Table 3). However, the concentration of volatiles at any given

296 time during the storage period was greater in samples dried at higher temperature

$297\left(60^{\circ} \mathrm{C}\right)$ compared to samples dried at lower temperature $\left(40^{\circ} \mathrm{C}\right.$; Table 1 and Table 2$)$.

298 These results are in agreement with the findings for storage of dried $\left(45^{\circ} \mathrm{C}\right.$ and $\left.90^{\circ} \mathrm{C}\right)$

299 tarragon leaves (Arabhosseini et al., 2007). It can be concluded that higher

300 temperature drying should be a desirable processing condition for prolonged storage

301 of cilantro. At the end of the storage period, while the concentration of majority of the 302 compounds decreased, an increase in concentration of nonane was observed. The 303 concentration of nonane was greater in samples derived from cilantro dried at $60^{\circ} \mathrm{C}$ 304 compared to those derived from cilantro dried at $40^{\circ} \mathrm{C}$ (Table 1).

305 Further, smaller particle size (CP) resulted in lowest concentration of volatiles in 306 the beginning and the end of the storage as compared to larger particle size (LF and 307 SF). Grinding of dried material results in increase in surface area and increase in 308 available sites for volatile loss and oxidation (Indiramma, 2005). Volatiles can be 309 retained for a longer time when dried herbs are not ground and sold whole, because 310 whole herbs deteriorate slower than ground spices (King, 2006). But, due to small 
311 bulk density of the whole dried cilantro $\left(0.2 \mathrm{~kg} / \mathrm{m}^{3}\right)$, packaging whole dried herb,

312 storage, and transportation will add to the cost.

313 The amount of volatile loss in dried cilantro samples was dependent on the initial

314 concentration of the volatile compound and the storage temperature. Further, initial

315 concentration of a compound at the start of the storage period was governed by pre-

316 processing conditions such as drying temperature and size reduction; higher

concentration in samples dried at $60^{\circ} \mathrm{C}$ and size reduced to LF or SF (Sekhon et al.,

2015). This may be due to inactivation of aldehydes reductases when cilantro was

dried at $60^{\circ} \mathrm{C}$ compared to when dried at $40^{\circ} \mathrm{C}$ (Quynh et al., 2010). In addition, lower

temperature drying resulted in longer drying time, which may have accelerated

volatile loss.

As opposed to the commercial retail of dried cilantro, one method of preserving aroma of dried herbs is low temperature storage (Negi and Roy, 2001; Paakkonen et al., 1990, Singh and Sagar, 2010). Losses in volatile compounds in an herb or a spice can be attributed to evaporation and oxidative reactions (Bera et al., 2001, Díaz-

Maroto et al., 2009) which are accelerated by elevated temperatures. In the present study, storage of samples at higher temperatures (elevated temperature and room temperature) led to a higher rate of volatile loss compared to storage at lower temperatures (freezer and refrigerator).

\subsubsection{Effect of propane extraction}

331 Extraction of dried cilantro with compressed propane did not negatively affect the

332 volatile composition during storage. The effect of propane extraction on concentration 333 of major volatile compounds in extracted and unextracted samples is shown in Figure

$3343 \mathrm{a}$ and Figure $3 \mathrm{~b}$. To compare extracted and unextracted samples, one extraction time 335 was selected. The selection of extraction time was based on the result that maximum 
extraction of volatile compounds was achieved when large flake and small flake samples were extracted for $40 \mathrm{~min}$ and CP samples were extracted for $20 \mathrm{~min}$.

The concentration of all volatile compounds in extracted samples, except nonane, decreased with increase in storage time similar to the trend observed in unextracted samples (Table 4). However, lower rate of volatile loss was observed in the extracted samples than in the unextracted samples (Table 3). This was true for all samples. Lower rate of volatile loss in extracted samples suggests solvent extraction with compressed propane may have stabilized volatile composition of dried cilantro.

However, the results need to be further investigated because in the present study the initial concentration of extracted sample at the beginning of storage was lower than the unextracted samples. Lower initial concentration can result in lower rate of volatile loss.

At the end of the storage period, the loss of major volatile compounds was least in the extracted samples stored in the freezer $(36-94 \%)$ followed by the samples stored in the refrigerator (38-94\%), at room temperature ( $87-98 \%)$, and at elevated temperature (94-99\%).

Regardless of the storage temperature, the concentration of nonane in extracted samples was greater in stored samples $(15.96-143.20 \mu \mathrm{g} / \mathrm{g})$ than in the control samples $(4.95-23.79 \mu \mathrm{g} / \mathrm{g})$. At the end of storage, the concentration of nonane was greater in samples derived from cilantro dried at $60^{\circ} \mathrm{C}$ than in those derived from cilantro dried at $40^{\circ} \mathrm{C}$. In addition, the concentration of nonane in $\mathrm{CP}$ was lower than in LF and SF. Increase in the concentration of nonane in dried cilantro samples during storage indicates breakdown of other compounds via chemical or enzymatic reactions into alkanes such as nonane. However, further investigation is required for the development of breakdown products other than nonane. Oxidation of fatty acids 
produces a number of compounds: alkanes, alkenes, ketones, aldehydes, alcohols, acids, esters, etc. (Frankel, 1984, Grosch, 1982). Nonane can be a break down product of such oxidation reaction. Decarboxylation of fatty acid produces alkanes with one or two carbon atoms less than the precursor fatty acid (Khan and Kolattukudy, 1974). Bognar et al. (1984) investigated conversion of higher carbon fatty acids (C-31) to shorter alkanes (by incubating pea leaf microsomes) in the presence of ascorbic acid (acts as fatty acid breakdown catalyst). Fresh pea leaves were homogenized and prepared as an enzyme source to convert fatty acid into alkane. The enzyme from pea leaves used C-32 acids as substrates producing C-31 as the major alkane (one carbon less than the corresponding fatty acid). But, fatty acid groups present in cilantro are in the range of $\mathrm{C}-16$ (palmitic acid, palmitoleic acid) to $\mathrm{C}-18$ (linoleic acid, $\alpha$-linolenic acid). It can be postulated that nonane was produced by decarboxylation of fatty acids in the presence of enzyme, but further investigation is required.

\section{Conclusions}

The present study demonstrated that propane extraction did not negatively affect the color and volatile composition of cilantro samples during prolonged storage. This study provided important insights in the storage of commercially available dried cilantro and showed a possibility for utilization of raffinates after extraction of herbs using compressed solvents such as propane. Preprocessing (drying temperature and size reduction) of cilantro plays a significant role in preserving color quality and volatile composition of propane extracted and unextracted cilantro samples during storage. Freezer and refrigerator storage temperature preserved better color quality (higher $-\mathrm{a}^{*}$ values, lower BI values) and volatile composition of dried cilantro. The rate volatile loss was greater in unextracted samples compared to extracted samples. Furthermore, the final concentration of a volatile compound after prolonged storage 
386 depends on the initial concentration of a volatile compound at the beginning of the 387 storage period, which depends on the preprocessing conditions.

\section{5. Acknowledgements}

389 The authors gratefully acknowledge financial support for this research by the

390 National Institute of Food and Agriculture, USDA, under Grant No. 2009-34150391 19849, 2010-34150-20664. 


\section{References}

Arabhosseini, A., Huisman, W., Van Boxtel, A. and Muller, J. 2007. Long-term effects of drying conditions on the essential oil and color of tarragon leaves during storage. Journal of Food Engineering, 79, 561-566.

Babovic, N., Djilas, S., Jadranin, M., Vajs, V., Ivanovic, J., Petrovic, S. \& Zizovic, I. (2010). Supercritical carbon dioxide extraction of antioxidant fractions from selected Lamiaceae herbs and their antioxidant capacity. Innovative Food Science and Emerging Technologies, 11, 90-107.

Baritaux, O., Richard, H., Touche, J. \& Derbesy, M. (2006). Effects of drying and storage of herbs and spices on the essential oil. Part I. Basil, Ocimum basilicum L. Flavour and Frarance Journal, 7, 267-271.

Bera, M.B., Shrivastava, D.C., Singh, C.J., Kumar, K.S. \& Sharma, Y.K. 2001. Development of cold grinding process, packaging and storage of cumin powder. Journal of Food Science and Technology (Mysore), 38, 257-259.

Bognar, A.L., Paliyath, G., Rogers, L. \& Koattukurdy, P.E. (1984). Biosynthesis of alkanes by particulate and solubilized enzyme preparations from pea leaves (Pisum sativum). Archives of Biochemistry and Biophysics, 225, 8-17.

Diaz-Maroto, M.C., Pardo, E.A., Castillo-Munoz, N., Diaz-Maroto, I.J. \& Perez-Coello, M.S. (2009). Effect of storage conditions on volatile composition of dried rosemary (Rosmarinus officinalis L.) leaves. Flavour and Frarance Journal, 24, 245-250.

Frankel, E.N. (1984). Lipid oxidation: mechanisms, products and biological significance. Journal of the American Oil Chemists' Society, 61, 1908-1917.

Freitas, L.D.S., Oliveira, J.V.D., Dariva, C., Jacques, R.A. \& Caramao, E.B. (2008). Extraction of Grape Seed Oil Using Compressed Carbon Dioxide and Propane:

Extraction Yields and Characterization of Free Glycerol Compounds. Journal of Agricultural and Food Chemistry, 56, 2558-2564.

Grosch, W. (1982). Lipid degradation products and flavours. In I.D. Morton \& A.J. Macleod (Eds), Food flavours: Part A. Introduction (pp. 325-398). Elsevier Scientific Publishing Company, Amsterdam, Netherlands.

Hamdana, S., Daooda, H.G., Toth-Markusa, M. \& Illesb, V. (2008). Extraction of cardamom oil by supercritical carbon dioxide and sub-critical propane. Journal of Supercritical Fluids, 44, 25-30.

Illes, V., Daood, H.G., Perneczki, S., Szokonya, L. \& Then, M. (2000). Extraction of coriander seed oil by $\mathrm{CO}_{2}$ and propane at super- and subcritical conditions. Journal of Agricultural and Food Chemistry, 17, 177-186.

Indiramma, A.R. (2005). Packaging aspects of spices and spice products. In Plastics in food packaging (pp. 207-222). Mysore, India.

Khan, A.A. \& Kolattukudy, P.E. (1974). Decarboxylation of long chain fatty acids to alkanes by cell free preparations of pea leaves (Pisum sativum). Biochemical and Biophysical Research Communications, 61, 1379-1386.

King, K. (2006). Packaging and storage of herbs and spices. Handbook of herbs and spices (Volume 3). Cambridge, England.

Negi, P. \& Roy, S. (2001). Effect of drying conditions on quality of green leaves during long term storage. Food Research International, 34, 283-287. 
Paakkonen, K., Malmsten, T. \& Hyvonen, L. (1990). Drying, packaging, and storage effects on quality of basil, marjoram and wild marjoram. Journal of Food Science, 55, 1373-1377.

Potter, T.L. (1996). Essential oil composition of cilantro. Journal of Agricultural and Food Chemistry, 44, 1824-1826.

Potter, T.L. \& Fagerson, I.S. (1990). Composition of coriander leaf volatiles. Journal of Agricultural and Food Chemistry, 38, 2054-2056.

Quynh, C. T., Iijima, Y., \& Kubota, K. (2010). Influence of the isolation procedure on coriander leaf volatiles with some correlation to the enzymatic activity. Journal of Agricultural and Food Chemistry, 58 (2), 1093-1099.

Ramanujam, S. (2014). Browning in foods.Defence Science Journal, 12 (2A), 1-12.

Rowshana, V., Bahmanzadegana, A. \& Saharkhizb, M.J. (2013). Influence of storage conditions on the essential oil composition of Thymus daenensis Celak. Industrial Crops Production, 49, 97-101.

Sekhon, J. K., Maness, N. O., \& Jones, C. L. (2015). Effect of preprocessing and compressed propane extraction on quality of cilantro (Coriandrum sativum L.). Food chemistry, 175, 322-328.

Sá, M., \& A. M. Sereno. (1999). The kinetics of browning measured during the storage of onion and strawberry. International Journal of Food science \& Technology. 34(4): 343-349.

Singh, U. \& Sagar, V.R. (2010). Quality characteristics of dehydrated leafy vegetables influenced by packaging materials and storage temperature. Journal of Scientific \& Industrial Research, 69, 785-789.

Sparks, D., R. Hernandez, M. Zappi, D. Blackwell, \& T. Fleming. (2006). Extraction of rice bran oil using supercritical carbon dioxide and propane. Journal of the American Oil Chemists'Society, 83, 885-891.

Steet, J.A. \& Tong, C.H. (1996). Degradation kinetics of green color and chlorophylls in peas by colorimetry and HPLC. Journal of Food Science, 61, 925-927.

Usai, M., Marchetti, M., Foddai, M., Caro, A.D., Desogus, R., Sanna, I. \& Piga, A. (2011). Influence of different stabilizing operations and storage time on the composition of essential oil of thyme (Thymus officinalis L.) and rosemary (Rosmarinus officinalis L.). LWT - Food Science and Technology, 44, 244-249. 


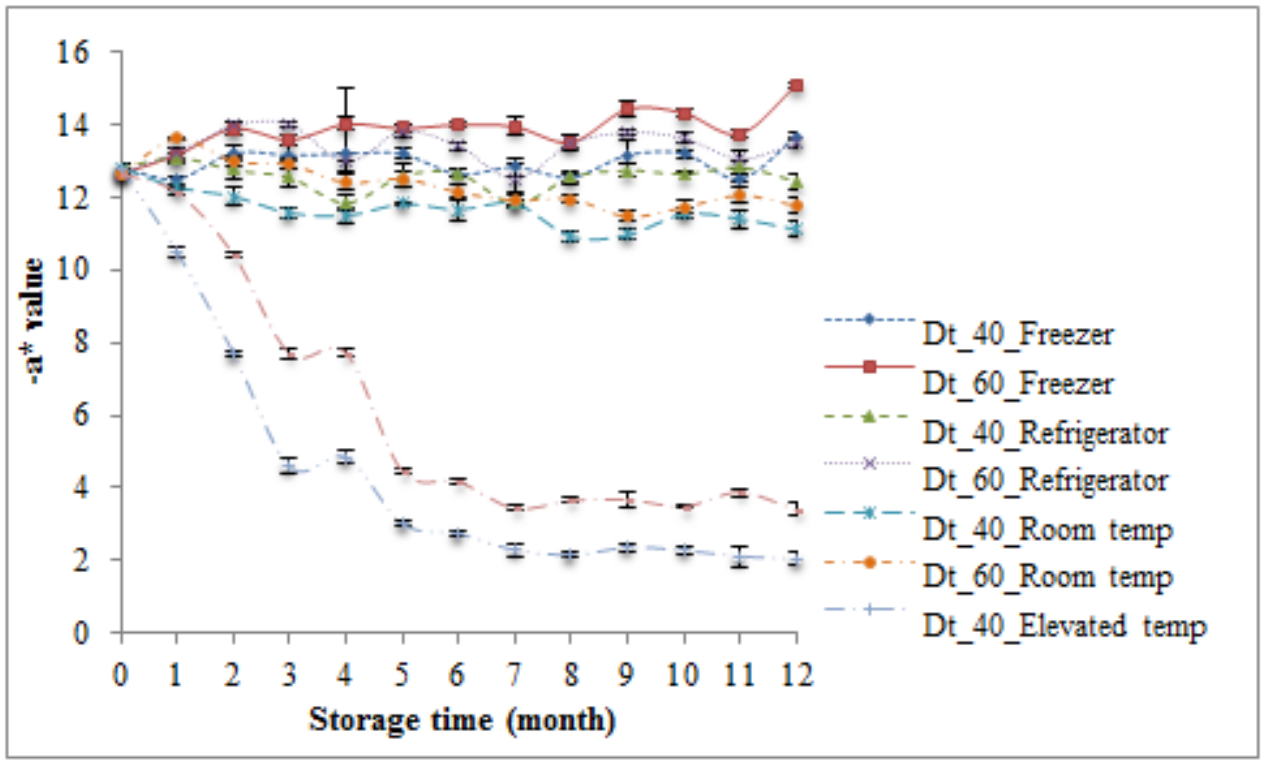

(a)

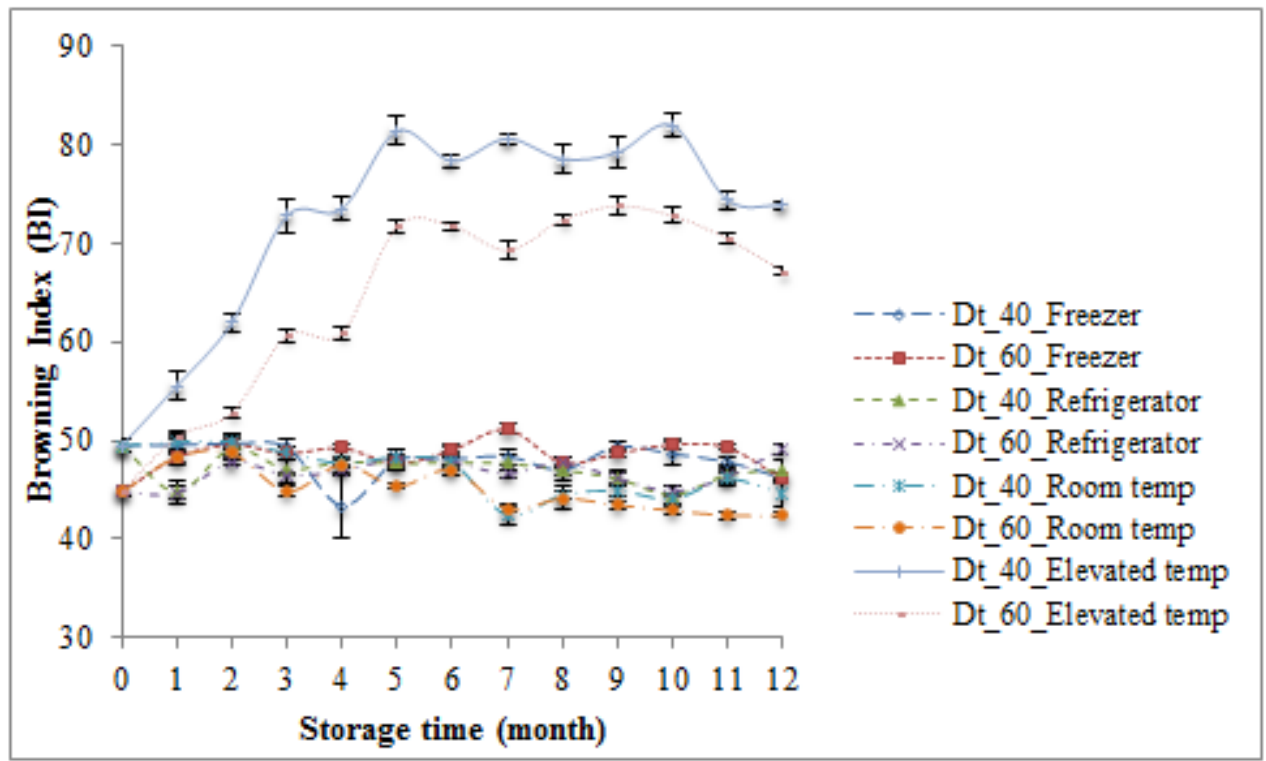

(b)

Figure 1. Effect of storage temperature and storage time on (a) $-a^{*}$ values and (b) browning index (BI) values of CP samples. CP: coarse powder (particle size $0.25-0.5 \mathrm{~mm}$ ), Legend Dt_40_Freezer means drying temperature was $40^{\circ} \mathbf{C}$ and $\mathrm{CP}$ was stored in Freezer; Storage temperature: Freezer $\left(-20^{\circ} \mathrm{C}\right)$, Refrigerator $\left(4.9^{\circ} \mathrm{C} \pm 0.56\right)$, at Room temperature $\left(23.3^{\circ} \mathrm{C}\right.$ $\pm 2.91 ; \mathrm{RH} 46.84 \% \pm 10.86)$ and Elevated temperature $\left(37.83^{\circ} \mathrm{C} \pm 4.12 ; \mathrm{RH} 70.45 \% \pm 18.87\right)$. Dt: drying temperature; temp: temperature. 


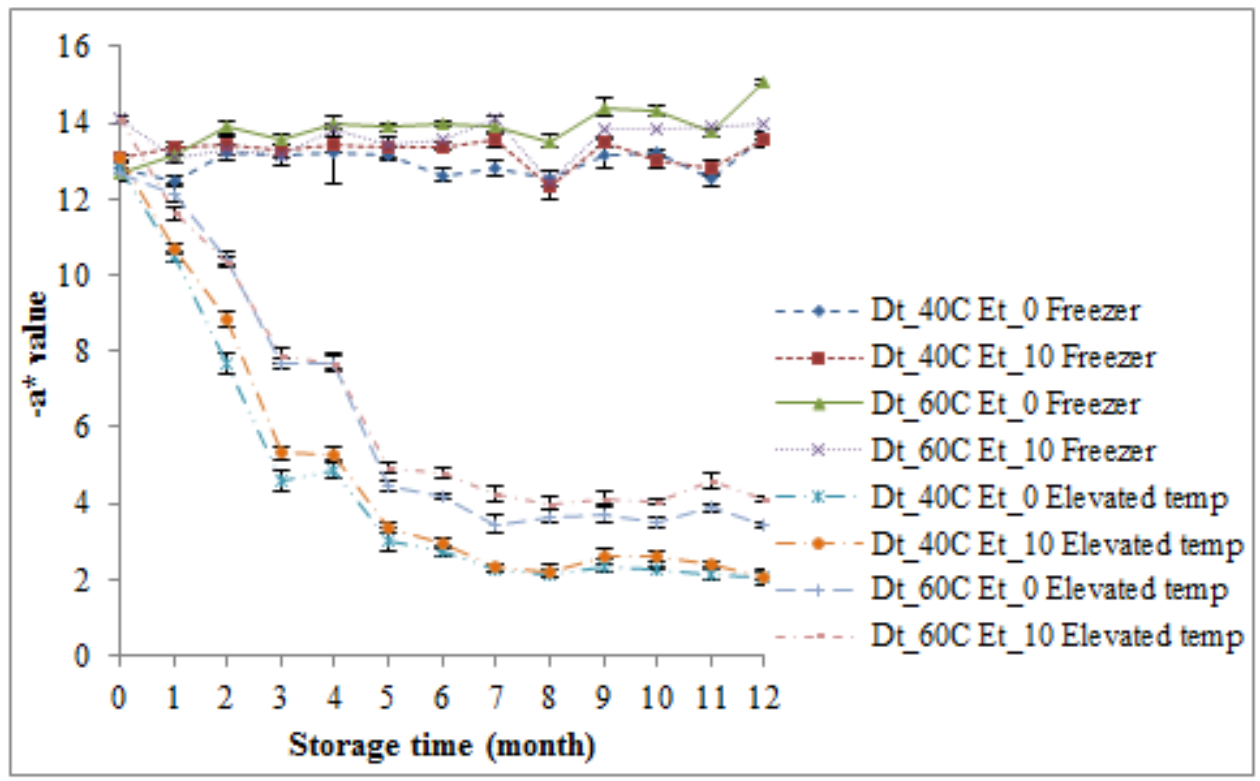

(a)

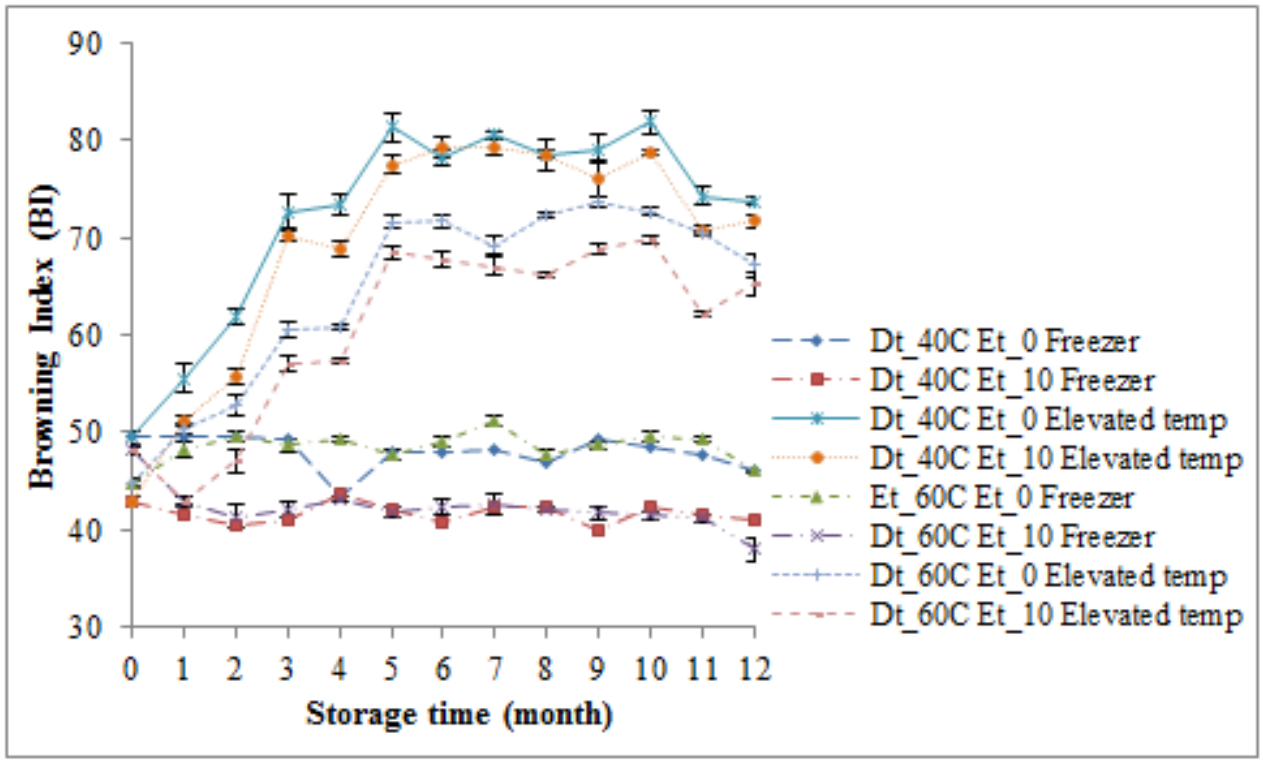

(b)

Figure 2. Effect of storage temperature and storage time on (a) $-a^{*}$ values and (b) browning index (BI) values of unextracted ( 0 min) and extracted (10 min) CP (coarse powder; particle size 0.25 - $0.5 \mathrm{~mm}$ ) samples.

Legend Dt_40C Et_0 Freezer means drying temperature was $40^{\circ} \mathrm{C}$, extraction time was 0 min and CP samples were stored in Freezer. Storage temperature: Freezer $\left(-20^{\circ} \mathrm{C}\right)$, Refrigerator $\left(4.9^{\circ} \mathrm{C} \pm 0.56\right)$, at Room temperature $\left(23.3^{\circ} \mathrm{C} \pm 2.91 ; \mathrm{RH} 46.84 \% \pm 10.86\right)$ and Elevated temperature $\left(37.83^{\circ} \mathrm{C} \pm 4.12 ; \mathrm{RH} 70.45 \% \pm 18.87\right)$.

Dt: drying temperature, Et: extraction time, temp: temperature. 


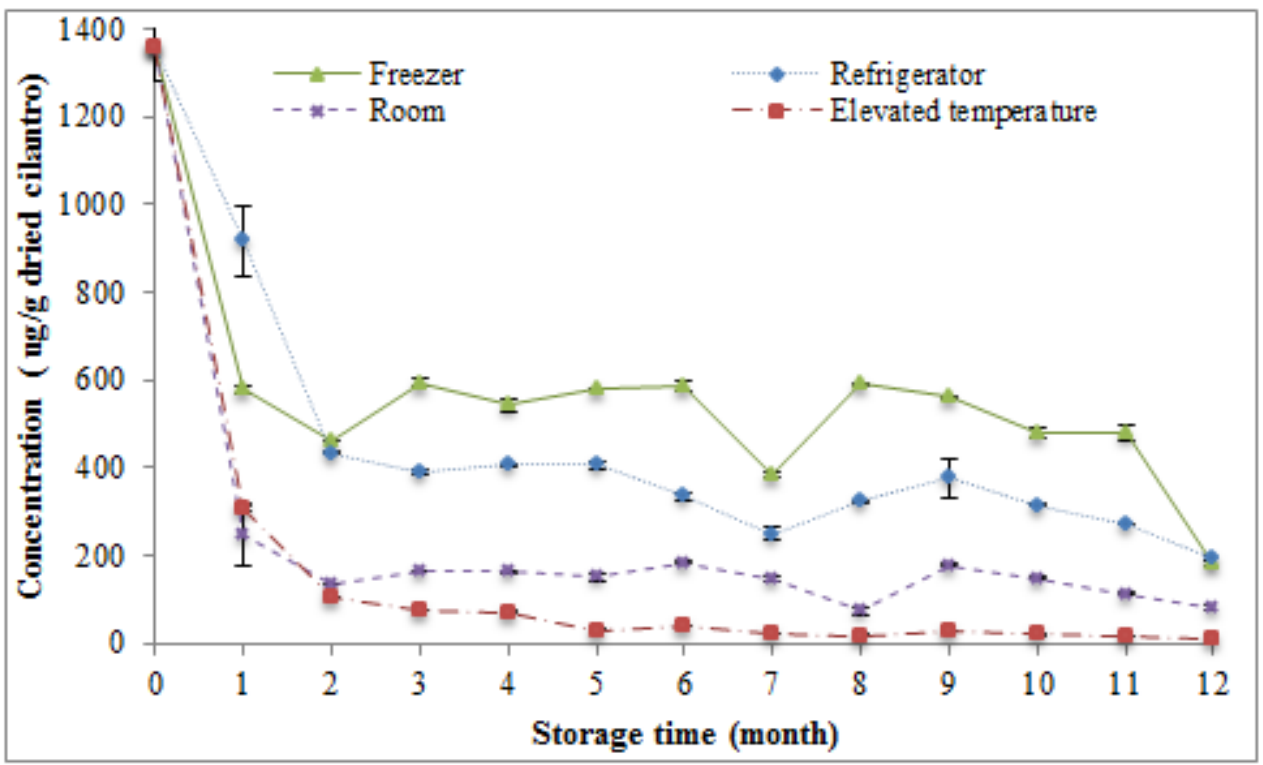

(a)

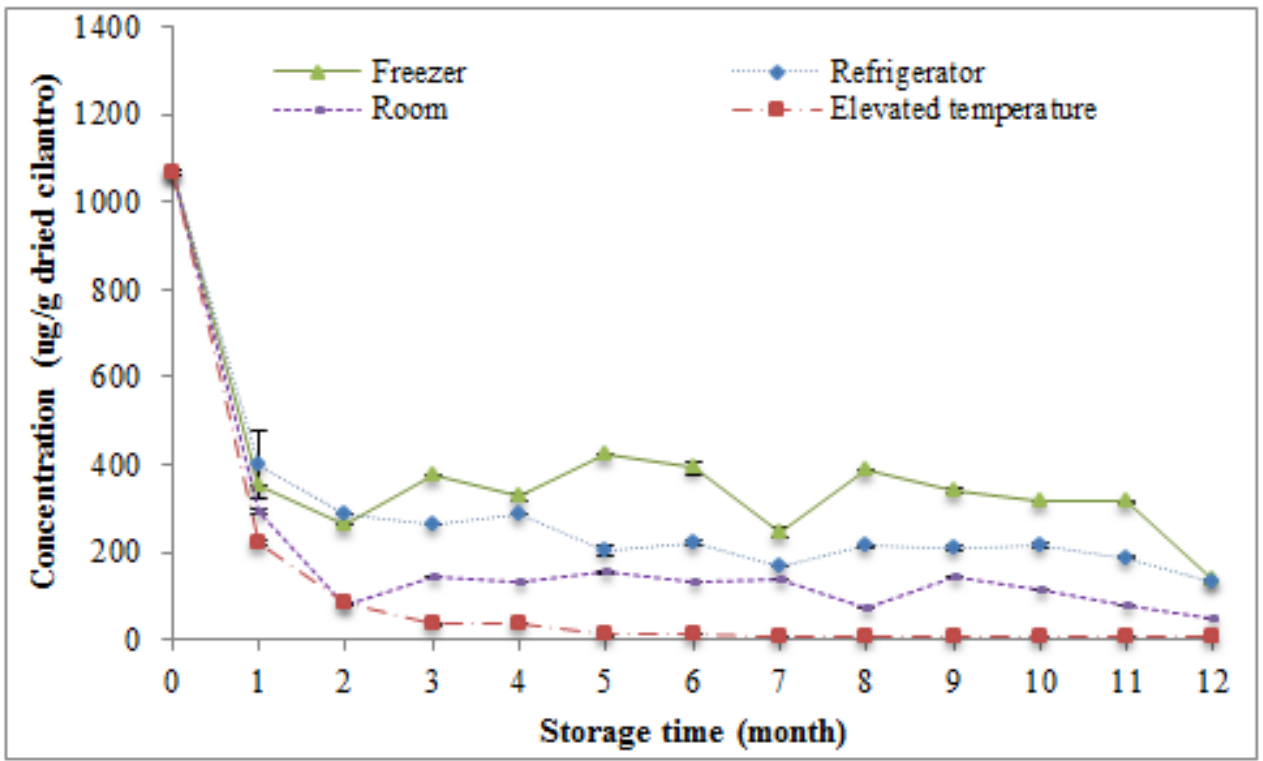

(b)

Figure 3. Effect of storage temperature on total concentration of major compounds ( $\mu \mathrm{g} / \mathrm{g}$ dried cilantro) in (a) unextracted and (b) propane extracted (40 min) SF samples. Storage temperature: Freezer $\left(-20^{\circ} \mathrm{C}\right)$, Refrigerator $\left(4.9^{\circ} \mathrm{C} \pm 0.56\right)$, at Room temperature $\left(23.3^{\circ} \mathrm{C} \pm 2.91\right.$; $\mathrm{RH} 46.84 \% \pm 10.86)$ and Elevated temperature $\left(37.83^{\circ} \mathrm{C} \pm 4.12 ; \mathrm{RH} 70.45 \% \pm 18.87\right)$.SF: small flakes (particle size $0.71-1.0 \mathrm{~mm}$; derived from cilantro dried $60^{\circ} \mathrm{C}$ ). 
Table 1. Effect of storage (12 month) on volatile concentration ( $\mu \mathrm{g} / \mathrm{g}$ dried cilantro) in unextracted large flakes (LF), small flakes (SF) and coarse powder (CP) derived from cilantro dried at $40^{\circ} \mathrm{C}$.

\begin{tabular}{|c|c|c|c|c|c|c|c|c|c|c|c|c|c|c|c|}
\hline Particle size* & & & $\mathrm{LF}$ & & & & & SF & & & & & $\mathrm{CP}$ & & \\
\hline $\begin{array}{c}\text { Storage temperature } \\
\left({ }^{\circ} \mathrm{C}\right)\end{array}$ & Control & Freezer $^{\mathrm{a}}$ & $\begin{array}{l}\text { Refriger } \\
\text { ator }^{b}\end{array}$ & Room $^{b}$ & $\begin{array}{l}\text { Elevated } \\
\mathrm{b}\left(40^{\circ} \mathrm{C}\right)\end{array}$ & Control & Freezer $^{\mathrm{a}}$ & $\begin{array}{l}\text { Refriger } \\
\text { ator }^{b}\end{array}$ & Room $^{b}$ & $\begin{array}{l}\text { Elevated } \\
\mathrm{b}\left(40^{\circ} \mathrm{C}\right)\end{array}$ & Control & Freezer $^{\mathrm{a}}$ & $\begin{array}{l}\text { Refriger } \\
\text { ator }^{b}\end{array}$ & Room $^{b}$ & $\begin{array}{l}\text { Elevated } \\
\mathrm{b}\left(40^{\circ} \mathrm{C}\right)\end{array}$ \\
\hline $\begin{array}{l}\text { Storage time } \\
\text { (months) }\end{array}$ & 0 & 12 & 12 & 12 & 12 & 0 & 12 & 12 & 12 & 12 & 0 & 12 & 12 & 12 & 12 \\
\hline Major & $798.4 a$ & 179.6b & $140.9 \mathrm{c}$ & 34.7d & $4.3 \mathrm{e}$ & $637.3 a$ & $109.6 b$ & $94.6 b$ & $33.5 c$ & 4.7d & 259.5a & 42.7b & $57.0 b$ & $12.5 \mathrm{c}$ & $1.8 \mathrm{c}$ \\
\hline Dodecanal & $156.5 \mathrm{a}$ & $16.5 \mathrm{c}$ & $23.2 b$ & $4.2 \mathrm{~d}$ & $0.6 \mathrm{~d}$ & $109.8 \mathrm{a}$ & $9.6 b$ & $8.7 b$ & $3.0 \mathrm{bc}$ & $0.6 \mathrm{c}$ & $56.1 \mathrm{a}$ & $5.1 b$ & $4.4 b$ & $1.2 b$ & $0.3 b$ \\
\hline E-2-Dodecenal & $59.8 \mathrm{a}$ & $20.1 \mathrm{c}$ & $29.0 \mathrm{~b}$ & $5.4 \mathrm{~d}$ & $0.3 \mathrm{e}$ & $74.1 \mathrm{a}$ & $10.3 \mathrm{bc}$ & $15.5 b$ & $6.1 \mathrm{~cd}$ & $0.3 \mathrm{~d}$ & $27.7 \mathrm{a}$ & $2.4 \mathrm{c}$ & $5.6 \mathrm{~b}$ & $1.3 \mathrm{c}$ & $0.2 \mathrm{c}$ \\
\hline Tetradecanal & $360.4 a$ & $36.7 b$ & $23.8 b$ & $6.3 \mathrm{c}$ & $1.0 \mathrm{c}$ & $185.5 \mathrm{a}$ & $25.5 b$ & $15.7 \mathrm{bc}$ & $3.5 \mathrm{~cd}$ & 1.5 & $67.1 \mathrm{a}$ & $14.2 \mathrm{~b}$ & $12.1 \mathrm{~b}$ & $1.9 \mathrm{~b}$ & $0.7 b$ \\
\hline E-2-Tetradecenal & $221.8 \mathrm{a}$ & $106.4 b$ & $64.8 \mathrm{c}$ & $18.8 \mathrm{~d}$ & $2.4 \mathrm{e}$ & $267.9 \mathrm{a}$ & $64.2 \mathrm{~b}$ & $54.7 \mathrm{~b}$ & $20.9 c$ & $2.3 \mathrm{~d}$ & $108.6 a$ & $20.9 c$ & $35.0 \mathrm{~b}$ & $8.1 \mathrm{~d}$ & $0.6 \mathrm{~d}$ \\
\hline Intermediate & 129.5 & 109.9 & 136.6 & 104.4 & 99.6b & $107.8 b$ & $98.4 a$ & 83.8a & $84.7 a$ & $87.2 a$ & $54.7 \mathrm{bc}$ & 40.7bc & $52.5 a$ & $34.2 \mathrm{c}$ & $42.5 b$ \\
\hline Nonane & $26.9 \mathrm{~d}$ & $90.5 b$ & $118.6 \mathrm{a}$ & $96.1 \mathrm{bc}$ & $93.9 b c$ & $6.6 b$ & $86.2 \mathrm{a}$ & $71.6 a$ & $78.2 \mathrm{a}$ & $82.8 \mathrm{a}$ & $4.9 c$ & $34.1 \mathrm{~b}$ & $45.5 \mathrm{a}$ & $31.3 \mathrm{~b}$ & $40.0 \mathrm{a}$ \\
\hline Octanal & $11.1 \mathrm{a}$ & $4.9 \mathrm{ab}$ & $3.4 \mathrm{~b}$ & $2.3 b$ & $2.6 \mathrm{~b}$ & $6.1 \mathrm{a}$ & $2.6 \mathrm{~b}$ & $1.7 \mathrm{c}$ & $1.6 \mathrm{c}$ & $1.9 \mathrm{c}$ & $5.5 \mathrm{a}$ & $1.3 b$ & $0.9 \mathrm{c}$ & $0.7 \mathrm{~d}$ & $0.9 \mathrm{c}$ \\
\hline Decanal & $24.1 \mathrm{a}$ & $4.3 b$ & $2.9 \mathrm{c}$ & $1.0 \mathrm{~d}$ & $0.3 \mathrm{~d}$ & $18.6 \mathrm{a}$ & $3.6 \mathrm{~b}$ & $1.9 \mathrm{~b}$ & $0.7 b$ & $0.1 b$ & $11.8 \mathrm{a}$ & $2.2 b$ & $0.9 \mathrm{c}$ & $0.4 \mathrm{~d}$ & $0.1 \mathrm{~d}$ \\
\hline Decanol & $9.1 \mathrm{a}$ & $1.5 b$ & $0.7 \mathrm{c}$ & $0.6 \mathrm{~cd}$ & $0.6 \mathrm{~d}$ & $1.5 \mathrm{a}$ & $0.4 \mathrm{ab}$ & $0.3 b$ & $0.4 \mathrm{ab}$ & $0.5 \mathrm{ab}$ & $0.6 \mathrm{a}$ & $0.2 b$ & $0.2 b$ & 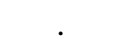 & $0.1 b$ \\
\hline Undecanal & $16.7 \mathrm{a}$ & $1.2 b$ & $1.3 b$ & $0.5 \mathrm{c}$ & $0.2 \mathrm{c}$ & $12.6 \mathrm{a}$ & $1.1 \mathrm{~b}$ & $0.9 \mathrm{~b}$ & $0.3 b$ & $0.3 b$ & $6.5 \mathrm{a}$ & $0.9 b$ & $0.6 b$ & $0.2 b$ & $0.1 b$ \\
\hline E-2-Dodecenol & . & $0.9 \mathrm{a}$ & $0.8 \mathrm{a}$ & $0.8 \mathrm{a}$ & $0.8 \mathrm{a}$ & $2.7 \mathrm{a}$ & $0.31 b$ & $2.5 \mathrm{a}$ & $0.5 b$ & $0.5 b$ & & $0.1 \mathrm{~b}$ & $1.0 \mathrm{a}$ & $0.2 b$ & $0.2 b$ \\
\hline Dodecanol & $4.9 \mathrm{a}$ & $1.9 \mathrm{~b}$ & $3.3 \mathrm{ab}$ & $1.1 \mathrm{~b}$ & $0.9 b$ & $2.0 \mathrm{a}$ & $0.6 \mathrm{~b}$ & $0.6 b$ & $0.6 b$ & $0.3 b$ & $1.7 \mathrm{a}$ & $0.2 b$ & $0.4 \mathrm{~b}$ & $0.3 b$ & $0.2 b$ \\
\hline Tridecanal & $13.1 \mathrm{a}$ & $1.8 b$ & $2.6 b$ & $1.4 \mathrm{~b}$ & $0.3 b$ & $24.6 \mathrm{a}$ & $1.5 b$ & $1.6 \mathrm{~b}$ & $1.5 b$ & $0.6 \mathrm{c}$ & $7.0 \mathrm{a}$ & $0.9 \mathrm{~b}$ & $1.2 b$ & $0.7 b$ & $0.3 b$ \\
\hline E-2-Tridecenal & $23.5 \mathrm{a}$ & $2.9 \mathrm{~b}$ & $3.1 \mathrm{~b}$ & $0.7 \mathrm{c}$ & $0.1 \mathrm{c}$ & $33.1 \mathrm{a}$ & $2.1 \mathrm{~b}$ & $2.6 \mathrm{~b}$ & $0.9 \mathrm{~b}$ & $0.4 \mathrm{~b}$ & $16.7 \mathrm{a}$ & $0.8 \mathrm{c}$ & $1.7 \mathrm{~b}$ & $0.4 \mathrm{c}$ & $0.6 \mathrm{c}$ \\
\hline Minor & $33.2 a$ & $20.5 b$ & 20.3b & $9.2 \mathrm{c}$ & $5.4 \mathrm{c}$ & 35.8a & 15.3ab & 13.0ab & $5.2 b$ & $6.8 \mathrm{~b}$ & 11.5a & 13.9a & 13.3a & $5.1 \mathrm{a}$ & $3.3 \mathbf{a}$ \\
\hline Phenylacetaldehyde & 1.76 & . & 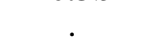 & & . & 3.3 & . & & 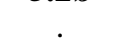 & & & & . & & . \\
\hline Linalool & 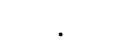 & $6.6 \mathrm{a}$ & $4.1 b$ & $2.4 \mathrm{c}$ & $2.1 \mathrm{c}$ & $1.1 \mathrm{c}$ & $3.9 \mathrm{a}$ & $2.4 \mathrm{~b}$ & $1.8 \mathrm{bc}$ & $2.2 b$ & $0.5 \mathrm{c}$ & $2.5 \mathrm{a}$ & $1.1 \mathrm{~b}$ & $0.8 \mathrm{ab}$ & $0.8 \mathrm{ab}$ \\
\hline Nonanal & $27.6 \mathrm{a}$ & $13.1 b c$ & $15.7 b$ & $6.8 \mathrm{~cd}$ & $3.2 \mathrm{~d}$ & $28.5 \mathrm{a}$ & $9.5 b$ & $10.6 \mathrm{~b}$ & $3.4 \mathrm{~b}$ & $4.6 \mathrm{~b}$ & $10.0 \mathrm{ab}$ & $13.4 \mathrm{a}$ & $12.2 \mathrm{a}$ & $4.0 \mathrm{~b}$ & $2.5 b$ \\
\hline E-2-Nonenal & 0.8 & 0.2 & - & • & . & 0.5 & 0.2 & • & . & . & . & . & . & . & . \\
\hline 9-Decenal & 1.1 & . & . & . & . & 0.7 & 1.3 & . & . & . & 0.9 & . & . & . & . \\
\hline 2-Decenal & 0.6 & . & . & . & 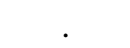 & 0.6 & . & . & . & . & . & . & . & . & . \\
\hline E-2-Undecenal & $1.3 \mathrm{a}$ & $0.5 b$ & $0.6 \mathrm{~b}$ & & $0.1 \mathrm{c}$ & 1.1 & 0.3 & & & & & & . & 0.3 & \\
\hline
\end{tabular}

$\mathrm{a}, \mathrm{b}, \mathrm{c}, \mathrm{d}$, e denote significantly different volatile concentration ( $\mu \mathrm{g} / \mathrm{g}$ dried cilantro) (at 0.05 probability level) between control samples, samples stored in freezer, refrigerator, room temperature and elevated temperature. ${ }^{a}$ Samples stored in freezer were packaged in glass bottles with plastic screw caps. ${ }^{b}$ samples stored in refrigerator, at room temperature, and at elevated temperature were packaged in Al foil laminate packages. *Particle size: LF: 0.85 - 1.18 mm, SF: 0.71 - 1.0 mm, $\mathrm{CP}: 0.25-0.5 \mathrm{~mm}$. Base on the concentration, volatile compounds were designated as major (concentration $>40 \mu \mathrm{g} / \mathrm{g}$ dried cilantro; intermediate $(4 \mu \mathrm{g} / \mathrm{g}$ to 40 $\mu \mathrm{g} / \mathrm{g}$ ) or minor (concentration $<4 \mu \mathrm{g} / \mathrm{g}$ dried cilantro). 
Table 2. Effect of twelve month storage on volatile concentration ( $\mu \mathrm{g} / \mathrm{g}$ dried cilantro) in unextracted large flakes (LF), small flakes (SF) and coarse powder (CP) derived from cilantro dried at $60^{\circ} \mathrm{C}$.

\begin{tabular}{|c|c|c|c|c|c|c|c|c|c|c|c|c|c|c|c|}
\hline \multirow{2}{*}{\begin{tabular}{|l} 
Particle size ${ }^{*}$ \\
$\begin{array}{l}\text { Storage temperature } \\
\left({ }^{\circ} \mathrm{C}\right)\end{array}$ \\
\end{tabular}} & \multicolumn{5}{|c|}{ LF } & \multicolumn{5}{|c|}{ SF } & \multicolumn{5}{|c|}{$\mathrm{CP}$} \\
\hline & Contro & Freeze & $\begin{array}{c}\text { Refrigera } \\
\text { tor }\end{array}$ & Room & $\begin{array}{c}\text { Elevated } \\
\left(40^{\circ} \mathrm{C}\right)\end{array}$ & Control & Freeze & $\begin{array}{c}\text { Refrigera } \\
\text { tor }\end{array}$ & Room $^{b}$ & $\begin{array}{c}\text { Elevated }^{\mathrm{b}} \\
\left(40^{\circ} \mathrm{C}\right)\end{array}$ & Control & Free & $\begin{array}{c}\text { Refrigera } \\
\text { tor }\end{array}$ & Room $^{b}$ & $\begin{array}{c}\text { Elevated }^{\mathrm{b}} \\
\left(40^{\circ} \mathrm{C}\right)\end{array}$ \\
\hline e time (months) & 0 & 12 & 12 & 12 & 12 & 0 & 12 & 12 & 12 & 12 & 0 & 12 & 12 & 12 & 12 \\
\hline \begin{tabular}{|l|} 
Major \\
Dodecanal \\
E-2-Dodecenal \\
Tetradecanal \\
E-2-Tetradecenal \\
\end{tabular} & $\begin{array}{c}1359.0 a \\
189.0 \mathrm{a} \\
145.5 \mathrm{a} \\
361.4 \mathrm{a} \\
663.2 \mathrm{a} \\
\end{array}$ & $\begin{array}{c}\text { 432.2b } \\
24.8 \mathrm{~b} \\
46.0 \mathrm{c} \\
47.7 \mathrm{~b} \\
313.6 \mathrm{~b} \\
\end{array}$ & $\begin{array}{c}316.1 \mathrm{c} \\
30.3 \mathrm{~b} \\
60.6 \mathrm{~b} \\
34.5 \mathrm{c} \\
190.7 \mathrm{c} \\
\end{array}$ & $\begin{array}{c}77.4 d \\
5.7 \mathrm{c} \\
14.8 \mathrm{~d} \\
8.6 \mathrm{~d} \\
48.3 \mathrm{~d} \\
\end{array}$ & $\begin{array}{l}\mathbf{1 1 . 4 e} \\
2.3 \mathrm{c} \\
2.3 \mathrm{e} \\
1.3 \mathrm{~d} \\
5.6 \mathrm{e}\end{array}$ & $\begin{array}{c}\text { 1356.6a } \\
169.9 \mathrm{a} \\
182.8 \mathrm{a} \\
235.3 \mathrm{a} \\
768.6 \mathrm{a} \\
\end{array}$ & $\begin{array}{c}\mathbf{1 8 1 . 8 b} \\
13.7 \mathrm{~b} \\
17.9 \mathrm{~b} \\
32.8 \mathrm{~b} \\
117.3 \mathrm{bc} \\
\end{array}$ & $\begin{array}{c}\text { 279.0b } \\
22.6 \mathrm{~b} \\
41.9 \mathrm{~b} \\
39.2 \mathrm{~b} \\
175.3 \mathrm{~b} \\
\end{array}$ & $\begin{array}{c}\text { 82.0bc } \\
7.0 \mathrm{~b} \\
16.3 \mathrm{~b} \\
8.2 \mathrm{~b} \\
50.5 \mathrm{~cd} \\
\end{array}$ & $\begin{array}{l}\mathbf{1 2 . 4 c} \\
2.2 \mathrm{~b} \\
1.9 \mathrm{~b} \\
1.7 \mathrm{~b} \\
6.5 \mathrm{~d} \\
\end{array}$ & \begin{tabular}{|c|}
$875.7 a$ \\
$142.4 \mathrm{a}$ \\
$90.1 \mathrm{a}$ \\
$258.3 \mathrm{a}$ \\
$384.9 \mathrm{a}$ \\
\end{tabular} & $\begin{array}{c}\mathbf{1 2 7 . 5 b} \\
13.4 \mathrm{~b} \\
9.5 \mathrm{~b} \\
36.2 \mathrm{~b} \\
68.3 \mathrm{~b} \\
\end{array}$ & $\begin{array}{c}\text { 118.4bc } \\
11.0 \mathrm{c} \\
14.8 \mathrm{~b} \\
26.5 \mathrm{~b} \\
66.1 \mathrm{~b} \\
\end{array}$ & $\begin{array}{l}42.9 \mathrm{c} \\
3.7 \mathrm{~d} \\
6.2 \mathrm{~b} \\
6.0 \mathrm{~b} \\
26.9 \mathrm{c} \\
\end{array}$ & $\begin{array}{l}3.2 \mathrm{c} \\
0.6 \mathrm{e} \\
0.1 \mathrm{~b} \\
0.8 \mathrm{~b} \\
1.7 \mathrm{c} \\
\end{array}$ \\
\hline Intermediate & $204.2 c$ & $226.8 \mathrm{a}$ & $157.8 \mathrm{c}$ & $145.5 c$ & $166.3 b$ & 198.6a & 131.8a & 207.6a & 143.8a & $147.5 a$ & 142.1a & $66.7 \mathrm{bc}$ & $76.4 b$ & $68.7 \mathrm{bc}$ & $60.7 c$ \\
\hline Nona & $22.4 d$ & $180.7 \mathrm{a}$ & $123.0 \mathrm{c}$ & $128.9 \mathrm{c}$ & $153.6 b$ & $20.4 b c$ & $111.4 \mathrm{ab}$ & $175.5 \mathrm{a}$ & $128.6 \mathrm{ab}$ & $129.6 \mathrm{ab}$ & $8.7 \mathrm{c}$ & $45.8 \mathrm{~b}$ & $62.9 \mathrm{a}$ & $61.3 \mathrm{a}$ & $56.9 \mathrm{a}$ \\
\hline Octanal & $7.2 \mathrm{a}$ & $6.7 \mathrm{a}$ & $4.3 b$ & $3.7 \mathrm{c}$ & $4.0 \mathrm{bc}$ & $8.8 \mathrm{a}$ & $3.3 \mathrm{ab}$ & $5.1 \mathrm{ab}$ & $3.2 b$ & $4.3 b$ & $8.3 \mathrm{a}$ & $2.1 b$ & $1.6 b$ & $1.6 \mathrm{~b}$ & $1.3 b$ \\
\hline Decanal & $26.8 \mathrm{a}$ & $5.8 \mathrm{~b}$ & $3.2 \mathrm{c}$ & $1.5 \mathrm{~d}$ & $0.6 \mathrm{e}$ & $34.7 \mathrm{a}$ & $4.8 b$ & $3.3 b$ & $1.4 \mathrm{~b}$ & $0.7 b$ & $25.3 \mathrm{a}$ & $4.9 b$ & $2.0 \mathrm{c}$ & $1.1 \mathrm{c}$ & $0.2 \mathrm{c}$ \\
\hline Deca & $19.8 \mathrm{a}$ & $4.6 \mathrm{~b}$ & $1.6 \mathrm{c}$ & $1.3 \mathrm{c}$ & $1.7 \mathrm{c}$ & $17.9 \mathrm{a}$ & $1.5 b$ & $1.3 b$ & $1.2 \mathrm{~b}$ & $3.1 \mathrm{~b}$ & $12.5 \mathrm{a}$ & $2.2 \mathrm{~b}$ & $0.6 \mathrm{c}$ & $0.5 \mathrm{c}$ & $1.1 \mathrm{bc}$ \\
\hline Un & $20.7 \mathrm{a}$ & $4.5 b$ & $1.2 \mathrm{c}$ & $0.6 \mathrm{~d}$ & $0.3 \mathrm{~d}$ & $21.8 \mathrm{a}$ & $2.4 \mathrm{~b}$ & $1.5 b$ & $0.6 b$ & $0.7 b$ & $15.6 \mathrm{a}$ & $2.7 b$ & $0.9 \mathrm{c}$ & $0.5 \mathrm{c}$ & $0.2 \mathrm{c}$ \\
\hline E-2-Dodecenol & & $8.8 \mathrm{a}$ & $7.3 \mathrm{a}$ & $2.5 b$ & $2.9 b$ & $30.6 a$ & $1.3 b$ & $4.1 \mathrm{~b}$ & $1.3 b$ & $4.5 b$ & & $3.8 \mathrm{a}$ & $1.4 \mathrm{~b}$ & $0.6 b$ & $0.2 b$ \\
\hline Dodec & $17.6 \mathrm{a}$ & $5.2 \mathrm{bc}$ & $7.9 \mathrm{~b}$ & $3.2 \mathrm{c}$ & $2.4 \mathrm{c}$ & $9.9 \mathrm{a}$ & $1.6 \mathrm{c}$ & $6.1 \mathrm{~b}$ & $3.1 \mathrm{c}$ & $3.5 \mathrm{c}$ & $13.5 \mathrm{a}$ & $2.0 \mathrm{~b}$ & $2.2 \mathrm{~b}$ & $1.4 \mathrm{~b}$ & $0.03 c$ \\
\hline Trid & $17.0 \mathrm{a}$ & $2.4 b$ & $3.3 b$ & $1.4 \mathrm{~b}$ & $0.4 \mathrm{c}$ & $3.4 \mathrm{ab}$ & $1.7 \mathrm{bc}$ & $3.7 \mathrm{a}$ & $1.4 \mathrm{bc}$ & $0.7 \mathrm{c}$ & $15.9 \mathrm{a}$ & $1.5 b$ & $2.2 b$ & $0.8 \mathrm{c}$ & $0.3 \mathrm{c}$ \\
\hline E-2-Tridecenal & $72.8 \mathrm{a}$ & $8.2 \mathrm{~b}$ & $5.9 \mathrm{~b}$ & $2.3 b$ & $0.3 b$ & $51.0 \mathrm{a}$ & $3.9 \mathrm{~b}$ & $6.9 \mathrm{~b}$ & $2.3 b$ & $0.5 b$ & 42.3 & $1.7 \mathrm{~b}$ & $2.6 \mathrm{~b}$ & $1.1 \mathrm{c}$ & $0.4 \mathrm{c}$ \\
\hline Minor & $29.4 a$ & 17.8ab & $22.4 a$ & $11.9 b$ & $7.7 b$ & 45.3a & 15.1b & $25.7 b$ & $12.5 b$ & $9.2 \mathrm{~b}$ & $21.7 a$ & 17.5b & $14.4 b$ & $10.4 b$ & $3.4 c$ \\
\hline Phenylace & 0.9 & & & & & & & & & & & & & & \\
\hline Linalool & & $6.8 \mathrm{a}$ & $4.5 b$ & $3.2 \mathrm{c}$ & $2.6 \mathrm{c}$ & $2.8 \mathrm{a}$ & $4.2 \mathrm{a}$ & $5.5 \mathrm{a}$ & $2.8 \mathrm{a}$ & $3.6 \mathrm{a}$ & $0.8 \mathrm{c}$ & $3.9 \mathrm{a}$ & $1.9 \mathrm{~b}$ & $1.1 \mathrm{c}$ & $1.2 \mathrm{c}$ \\
\hline Nona & $22.4 \mathrm{a}$ & $9.7 b$ & $16.6 \mathrm{ab}$ & $8.7 b$ & $5.1 b$ & $33.9 \mathrm{a}$ & $10.2 \mathrm{a}$ & $20.1 \mathrm{a}$ & $9.7 \mathrm{a}$ & $5.3 \mathrm{a}$ & $17.1 \mathrm{a}$ & $13.3 \mathrm{a}$ & $12.2 \mathrm{ab}$ & $9.3 b$ & $1.7 \mathrm{c}$ \\
\hline & 0.8 & 0.1 & • & . & . & 0.8 & 0.2 & . & . & 0.3 & 0.8 & . & . & . & . \\
\hline 9-Decenal & 0.6 & . & . & . & . & 1.1 & & . & . & . & 0.9 & . & . & . & 0.5 \\
\hline 2-Decenal & 1.4 & 0.2 & & . & . & 1.2 & 0.1 & . & . & . & 0.9 & 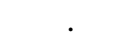 & 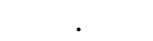 & . & . \\
\hline E-2-Undecenal & $3.4 \mathrm{a}$ & $0.9 \mathrm{~b}$ & $1.3 \mathrm{~b}$ & & & 3.4 & 0.5 & & & & 1.2 & 0.3 & 0.2 & & \\
\hline
\end{tabular}

$\mathrm{a}, \mathrm{b}, \mathrm{c}, \mathrm{d}$, e denote significantly different volatile concentration ( $\mu \mathrm{g} / \mathrm{g}$ dried cilantro) (at 0.05 probability level) between control samples, samples stored in freezer, refrigerator, room temperature and elevated temperature. ${ }^{a}$ Samples stored in freezer were packaged in glass bottles with plastic screw caps. ${ }^{\mathrm{b}}$ samples stored in refrigerator, at room temperature, and at elevated temperature were packaged in Al foil laminate packages. *Particle size: LF: 0.85 - 1.18 mm, SF: 0.71 - 1.0 mm, $\mathrm{CP}: 0.25-0.5 \mathrm{~mm}$. Based on the concentration, volatile compounds were designated as major (concentration $>40 \mu \mathrm{g} / \mathrm{g}$ dried cilantro; intermediate (4 $\mu \mathrm{g} / \mathrm{g}$ to 40 $\mu \mathrm{g} / \mathrm{g}$ ) or minor (concentration $<4 \mu \mathrm{g} / \mathrm{g}$ dried cilantro). 
Table 3. Rate of volatile loss in extracted and unextracted large flakes (LF), small flakes (SF) and coarse powder (CP) after 2months of storage in freezer, in refrigerator, at room temperature and at elevated temperature.

\begin{tabular}{|c|c|c|c|c|c|c|}
\hline \multirow{3}{*}{$\begin{array}{c}\text { Particle } \\
\text { size* }^{*}\end{array}$} & \multirow{3}{*}{$\begin{array}{c}\text { Drying } \\
\text { temperature } \\
\left({ }^{\circ} \mathrm{C}\right)\end{array}$} & \multirow{3}{*}{ Storage temperature } & Unextracted & Extracted $^{\mathrm{a}}$ & Unextracted & Extracted $^{\mathrm{a}}$ \\
\hline & & & \multicolumn{4}{|c|}{ Storage time (months) } \\
\hline & & & 1 & 1 & 2 & 2 \\
\hline \multirow{8}{*}{ 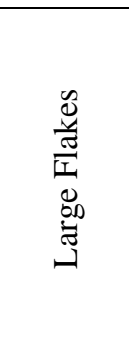 } & \multirow[t]{4}{*}{40} & Freezer $^{\mathrm{b}}$ & 11.5 & 7.7 & 2.4 & 1.4 \\
\hline & & Refrigerator $^{\mathrm{c}}$ & 0 & 0 & 19.8 & 10.6 \\
\hline & & Room temperature ${ }^{c}$ & 17.5 & 8.1 & 5.2 & 3.8 \\
\hline & & Elevated temperature $^{c}$ & 20.4 & 11.3 & 3.7 & 2.6 \\
\hline & \multirow[t]{4}{*}{60} & Freezer $^{\mathrm{b}}$ & 13.8 & 15.9 & 4.5 & 1.4 \\
\hline & & Refrigerator $^{\mathrm{c}}$ & 0.8 & 0 & 24.2 & 18.2 \\
\hline & & Room temperature $^{c}$ & 21.1 & 14.7 & 15.7 & 9.2 \\
\hline & & Elevated temperature $^{c}$ & 30.8 & 20.7 & 9.7 & 6.2 \\
\hline \multirow{8}{*}{ 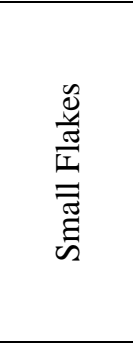 } & \multirow[t]{4}{*}{40} & Freezer $^{\mathrm{b}}$ & 9.1 & 7.7 & 5.2 & 1.5 \\
\hline & & Refrigerator $^{\mathrm{c}}$ & 12.9 & 7.0 & 1.7 & 2.0 \\
\hline & & Room temperature & 18.0 & 10.1 & 1.8 & 1.5 \\
\hline & & Elevated temperature $^{c}$ & 16.9 & 10.9 & 3.4 & 1.3 \\
\hline & \multirow[t]{4}{*}{60} & Freezer $^{b}$ & 26.0 & 23.7 & 3.9 & 3.0 \\
\hline & & Refrigerator $^{\mathrm{c}}$ & 14.7 & 22.2 & 16.1 & 3.7 \\
\hline & & Room temperature ${ }^{c}$ & 36.3 & 25.8 & 4.4 & 7.0 \\
\hline & & Elevated temperature $^{\mathrm{c}}$ & 35.0 & 28.1 & 6.7 & 4.6 \\
\hline \multirow{8}{*}{$\begin{array}{l}\dot{\bar{\theta}} \\
\overline{0} \\
0 \\
0 \\
0 \\
0 \\
\tilde{D} \\
0\end{array}$} & \multirow[t]{8}{*}{40} & Freezer $^{\mathrm{b}}$ & 3.2 & 2.3 & 1.7 & 1.0 \\
\hline & & Refrigerator $^{\mathrm{c}}$ & 5.0 & 2.5 & 0.1 & 0.7 \\
\hline & & Room temperature $^{c}$ & 4.3 & 2.1 & 2.4 & 2.0 \\
\hline & & Elevated temperature $^{\mathrm{c}}$ & 7.2 & 4.2 & 1.0 & 0.7 \\
\hline & & Freezer $^{\mathrm{b}}$ & 16.7 & 8.6 & 2.3 & 1.9 \\
\hline & & Refrigerator $^{\mathrm{c}}$ & 16.3 & 6.6 & 3.7 & 2.6 \\
\hline & & Room temperature $^{c}$ & 20.3 & 6.7 & 5.4 & 4.1 \\
\hline & & Elevated temperature $^{c}$ & 23.5 & 9.0 & 3.6 & 3.4 \\
\hline
\end{tabular}

${ }^{\mathrm{a}}$ Large flakes and small flakes extracted for 40 minutes and coarse powder extracted for 20 minutes. ${ }^{\mathrm{b}}$ Samples stored in freezer were packaged in glass bottles with plastic screw caps. ${ }^{c}$ samples stored in refrigerator, at room temperature, and at elevated temperature were packaged in Al foil laminate packages. Rate of volatile loss $\left(\mu \mathrm{g} /\right.$ day) was calculated as $\left(\mathrm{C}_{\mathrm{i}}-\mathrm{C}_{\mathrm{j}}\right) / 30, \mathrm{C}=$ concentration of volatile compound, $\mu \mathrm{g} / \mathrm{g}$ dried cilantro; $\mathrm{i}=$ month, $\mathrm{j}=\mathrm{i}+1$. *Particle size: $\mathrm{LF}: 0.85-1.18$ mm, SF: $0.71-1.0 \mathrm{~mm}, \mathrm{CP}: 0.25-0.5 \mathrm{~mm}$. 
Table 4. Effect of 12 month storage on volatile concentration ( $\mu \mathrm{g} / \mathrm{g}$ dried cilantro) in extracted large flakes (LF), small flakes (SF) and coarse powder (CP) derived from cilantro dried at $60^{\circ} \mathrm{C}$.

\begin{tabular}{|c|c|c|c|c|c|c|c|c|c|c|c|c|c|c|c|}
\hline Particle size* & \multicolumn{5}{|c|}{ LF } & \multicolumn{5}{|c|}{ SF } & \multicolumn{5}{|c|}{$\mathrm{CP}$} \\
\hline Extraction time (min) & \multicolumn{5}{|c|}{40} & \multicolumn{5}{|c|}{40} & \multicolumn{5}{|c|}{20} \\
\hline Storage & Control & Freezer $^{\mathrm{a}}$ & $\begin{array}{c}\text { Refri- } \\
\text { gerator }^{b}\end{array}$ & Room $^{\mathrm{b}}$ & $\begin{array}{c}\text { Elevated }^{\mathrm{b}} \\
\left(40^{\circ} \mathrm{C}\right)\end{array}$ & Control & Freezer $^{\mathrm{a}}$ & $\begin{array}{l}\text { Refri- } \\
\text { gerator }^{b}\end{array}$ & Room $^{b}$ & $\begin{array}{c}\text { Elevated }^{b} \\
\left(40^{\circ} \mathrm{C}\right)\end{array}$ & Control & Freezer $^{\mathrm{a}}$ & $\begin{array}{l}\text { Refri- } \\
\text { gerator }^{b}\end{array}$ & Room $^{\mathrm{b}}$ & $\begin{array}{c}\text { Elevated }^{\mathrm{b}} \\
\left(40^{\circ} \mathrm{C}\right)\end{array}$ \\
\hline Storage time (months) & 0 & 12 & 12 & 12 & 12 & 0 & 12 & 12 & 12 & 12 & 0 & 12 & 12 & 12 & 12 \\
\hline Major & $907.9 a$ & 204.0b & $192.5 b$ & $55.9 c$ & 6.6d & $1065.2 \mathrm{a}$ & $136.7 b$ & $130.5 b$ & $49.8 \mathrm{c}$ & $6.5 \mathrm{~d}$ & 415.9a & $56.9 b$ & $12.5 \mathrm{c}$ & $1.8 \mathrm{~d}$ & $1.8 d$ \\
\hline Dodecanal & $133.9 \mathrm{a}$ & $11.7 \mathrm{c}$ & $21.4 \mathrm{~b}$ & $4.4 \mathrm{~d}$ & $1.2 \mathrm{~d}$ & $153.1 \mathrm{a}$ & $9.3 b$ & $8.5 b$ & $3.6 \mathrm{c}$ & $1.2 \mathrm{~d}$ & $63.4 \mathrm{a}$ & $4.4 b$ & $1.2 b$ & $0.3 b$ & $0.3 b$ \\
\hline E-2-Dodecenal & $102.4 \mathrm{a}$ & $23.2 \mathrm{c}$ & $39.1 b$ & $10.0 \mathrm{~d}$ & $0.9 \mathrm{e}$ & $145.4 \mathrm{a}$ & $15.4 \mathrm{~b}$ & $23.6 \mathrm{c}$ & $9.9 \mathrm{~d}$ & $0.5 \mathrm{e}$ & $48.8 \mathrm{a}$ & $5.6 \mathrm{~b}$ & $1.3 \mathrm{c}$ & $0.2 \mathrm{c}$ & $0.2 \mathrm{c}$ \\
\hline Tetradecanal & $248.8 \mathrm{qa}$ & $23.6 \mathrm{~b}$ & $22.1 \mathrm{~b}$ & $6.1 \mathrm{c}$ & $1.3 \mathrm{~d}$ & $192.7 \mathrm{a}$ & $17.6 \mathrm{~b}$ & $12.6 \mathrm{~b}$ & $3.3 \mathrm{bc}$ & $1.2 \mathrm{c}$ & $77.9 \mathrm{a}$ & $12.1 \mathrm{~b}$ & $1.9 \mathrm{c}$ & $0.7 \mathrm{c}$ & $0.6 \mathrm{c}$ \\
\hline E-2-Tetradecenal & $422.8 \mathrm{a}$ & $145.5 b$ & $109.9 \mathrm{c}$ & $35.4 \mathrm{~d}$ & $3.2 \mathrm{e}$ & $574.0 \mathrm{a}$ & $94.4 b$ & $85.7 \mathrm{c}$ & $33.0 \mathrm{~d}$ & $3.6 \mathrm{e}$ & $225.8 \mathrm{a}$ & $35.0 \mathrm{~b}$ & $8.1 \mathrm{c}$ & $0.6 \mathrm{~d}$ & $0.7 \mathrm{~d}$ \\
\hline Intermediate & $145.2 \mathrm{a}$ & $168.5 b$ & $142.4 c$ & 129.1c & $125.8 \mathrm{c}$ & 193.5b & $125.2 \mathrm{~b}$ & $100.0 b$ & $118.5 b$ & $206.6 a$ & 91.1a & $52.5 a$ & $34.2 \mathrm{c}$ & $42.5 b$ & $45.3 b$ \\
\hline Nonane & $23.8 \mathrm{a}$ & $143.2 b$ & $118.6 \mathrm{c}$ & $118.1 \mathrm{c}$ & $117.1 \mathrm{c}$ & $23.7 b$ & $109.7 b$ & $87.3 b$ & $110.7 b$ & $194.9 \mathrm{a}$ & $9.4 \mathrm{c}$ & $45.5 \mathrm{a}$ & $31.3 b$ & $40.0 \mathrm{a}$ & $42.1 \mathrm{a}$ \\
\hline Octanal & $6.9 \mathrm{a}$ & $4.5 b$ & $3.5 \mathrm{c}$ & $3.2 \mathrm{c}$ & $3.1 \mathrm{c}$ & $6.7 \mathrm{a}$ & $2.5 b$ & $1.9 \mathrm{c}$ & $1.9 \mathrm{c}$ & $3.8 \mathrm{~b}$ & $8.6 a$ & $0.9 b$ & $0.7 b$ & $0.9 \mathrm{~b}$ & $0.8 b$ \\
\hline Decanal & $18.2 \mathrm{a}$ & $3.4 \mathrm{~b}$ & $1.9 \mathrm{c}$ & $1.1 \mathrm{~d}$ & $0.3 \mathrm{e}$ & $30.9 \mathrm{a}$ & $3.3 b$ & $1.4 \mathrm{bc}$ & $0.9 b c$ & $0.4 \mathrm{c}$ & $10.3 \mathrm{a}$ & $0.9 \mathrm{~b}$ & $0.4 \mathrm{~b}$ & $0.1 b$ & $0.1 b$ \\
\hline Decanol & $12.9 \mathrm{a}$ & $2.4 \mathrm{~b}$ & $0.9 \mathrm{c}$ & $1.0 \mathrm{c}$ & $1.1 \mathrm{c}$ & $9.11 \mathrm{a}$ & $1.3 b$ & $0.5 \mathrm{c}$ & $0.6 \mathrm{c}$ & $1.9 \mathrm{~b}$ & $1.6 \mathrm{a}$ & $0.2 b$ & . & $0.1 b$ & $0.5 b$ \\
\hline Undecanal & $14.2 \mathrm{a}$ & $2.4 \mathrm{~b}$ & $0.9 \mathrm{c}$ & $0.5 \mathrm{~d}$ & $0.2 \mathrm{e}$ & $18.9 \mathrm{a}$ & $1.6 \mathrm{~b}$ & $0.6 b$ & $0.3 b$ & $0.5 b$ & $6.0 \mathrm{a}$ & $0.6 b$ & $0.2 b$ & $0.1 b$ & $0.2 b$ \\
\hline E-2-Dodecenol & . & $3.7 \mathrm{~b}$ & $4.4 \mathrm{a}$ & $0.8 \mathrm{~d}$ & $1.6 \mathrm{c}$ & $8.7 \mathrm{a}$ & $0.6 b$ & $0.9 \mathrm{~b}$ & $0.3 \mathrm{c}$ & $2.8 \mathrm{~b}$ & . & $1.0 \mathrm{a}$ & $0.2 b$ & $0.2 b$ & $0.7 \mathrm{a}$ \\
\hline Dodecanol & $10.2 \mathrm{a}$ & $3.3 \mathrm{ab}$ & $5.0 \mathrm{ab}$ & $1.9 \mathrm{~b}$ & $1.9 \mathrm{~b}$ & $3.2 \mathrm{a}$ & $1.5 \mathrm{bc}$ & $1.9 \mathrm{~b}$ & $1.1 \mathrm{c}$ & $1.4 \mathrm{bc}$ & $13.1 \mathrm{a}$ & $0.4 \mathrm{~b}$ & $0.3 b$ & $0.2 b$ & $0.2 b$ \\
\hline Tridecanal & $14.8 \mathrm{a}$ & $1.5 \mathrm{c}$ & $2.2 \mathrm{~b}$ & $0.9 \mathrm{c}$ & $0.2 \mathrm{~d}$ & $18.3 \mathrm{a}$ & $1.0 \mathrm{~b}$ & $1.4 \mathrm{~b}$ & $1.0 \mathrm{~b}$ & $0.5 b$ & $7.9 \mathrm{a}$ & $1.2 \mathrm{~b}$ & $0.7 b$ & $0.3 \mathrm{c}$ & $0.2 \mathrm{c}$ \\
\hline E-2-Tridecenal & $44.3 \mathrm{a}$ & $4.1 \mathrm{~b}$ & $4.8 \mathrm{~b}$ & $1.6 \mathrm{c}$ & $0.2 \mathrm{c}$ & $74.0 \mathrm{a}$ & $3.6 \mathrm{~b}$ & $4.1 \mathrm{~b}$ & $1.6 \mathrm{~b}$ & $0.5 \mathrm{c}$ & $34.2 \mathrm{a}$ & $1.7 \mathrm{~b}$ & $0.4 \mathrm{c}$ & $0.6 \mathrm{c}$ & $0.5 \mathrm{c}$ \\
\hline Minor & $14.6 a$ & $16.4 a$ & 17.1a & $8.7 b$ & $4.5 b$ & $52.0 a$ & $10.7 \mathbf{a}$ & $10.2 a$ & $6.4 a$ & $8.8 \mathrm{a}$ & 10.1a & $13.3 \mathrm{a}$ & $4.8 b$ & $3.3 b$ & $3.9 \mathrm{~b}$ \\
\hline Phenylacetaldehyde & 0.9 & & & & & 3.6 & & & & & & . & & . & \\
\hline Linalool & . & $4.1 \mathrm{a}$ & $3.4 \mathrm{~b}$ & $2.4 \mathrm{c}$ & $2.1 \mathrm{c}$ & $1.4 \mathrm{c}$ & $2.6 \mathrm{a}$ & $1.9 \mathrm{~b}$ & $1.5 \mathrm{c}$ & $2.6 \mathrm{a}$ & $0.5 b$ & $1.1 \mathrm{a}$ & $0.8 \mathrm{a}$ & $0.8 \mathrm{a}$ & $0.6 b$ \\
\hline Nonanal & $9.4 \mathrm{ab}$ & $11.5 \mathrm{ab}$ & $12.8 \mathrm{a}$ & $6.3 \mathrm{bc}$ & $2.4 \mathrm{c}$ & $41.9 \mathrm{a}$ & $7.5 \mathrm{a}$ & $8.2 \mathrm{a}$ & $4.9 \mathrm{a}$ & $5.8 \mathrm{a}$ & $8.0 \mathrm{a}$ & $12.2 \mathrm{a}$ & $4.0 \mathrm{~b}$ & $2.5 b$ & $1.8 \mathrm{~b}$ \\
\hline E-2-Nonenal & 0.7 & 0.1 & 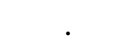 & . & $\cdot$ & 0.8 & 0.1 & & . & 0.5 & 0.8 & . & . & . & 0.2 \\
\hline 9-Decenal & 0.5 & 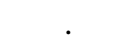 & . & . & 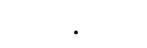 & 0.9 & . & & . & . & 0.8 & . & . & . & 0.9 \\
\hline 2-Decenal & 0.8 & 0.1 & . & . & 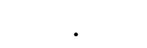 & 1.2 & 0.1 & . & . & . & . & . & . & . & 0.2 \\
\hline E-2-Undecenal & $2.3 \mathrm{a}$ & $0.5 \mathrm{c}$ & $0.9 \mathrm{~b}$ & $\cdot$ & & 2.1 & 0.4 & & . & . & . & . & & . & 0.2 \\
\hline
\end{tabular}

$\mathrm{a}, \mathrm{b}, \mathrm{c}, \mathrm{d}$, e denote significantly different volatile concentration ( $\mu \mathrm{g} / \mathrm{g}$ dried cilantro) (at 0.05 probability level) between control samples, samples stored in freezer, refrigerator, room temperature and elevated temperature. ${ }^{\mathrm{a}}$ Samples stored in freezer were packaged in glass bottles with plastic screw caps. ${ }^{\mathrm{b}}$ samples stored in refrigerator, at room temperature, and at elevated temperature were packaged in Al foil laminate packages. *Particle size: LF: 0.85 - 1.18 mm, SF: 0.71 - $1.0 \mathrm{~mm}, \mathrm{CP}: 0.25-0.5 \mathrm{~mm}$. Based on the concentration, volatile compounds were designated as major (concentration $>40 \mu \mathrm{g} / \mathrm{g}$ dried cilantro; intermediate $(4$ $\mu \mathrm{g} / \mathrm{g}$ to $40 \mu \mathrm{g} / \mathrm{g}$ ) or minor (concentration $<4 \mu \mathrm{g} / \mathrm{g}$ dried cilantro). 
Table S1. Moisture content (\% wb) in dried cilantro samples at the beginning and the end of storage period.

\begin{tabular}{|c|c|c|c|c|c|c|c|c|c|}
\hline \multirow{2}{*}{$\begin{array}{l}\text { Particle } \\
\text { size* }\end{array}$} & \multirow{2}{*}{$\begin{array}{l}\text { Drying temperature }\left({ }^{\circ} \mathrm{C}\right) \\
\text { Extraction time }(\mathrm{min})\end{array}$} & \multicolumn{4}{|c|}{40} & \multicolumn{4}{|c|}{60} \\
\hline & & 0 & 10 & 20 & 40 & 0 & 10 & 20 & 40 \\
\hline \multirow{5}{*}{ 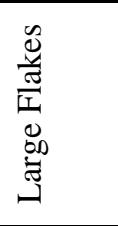 } & Control $^{\mathrm{a}}$ & $4.8 \pm 0.5$ & $4.9 \pm 0.3$ & $5.0 \pm 0.6$ & $5.4 \pm 0.7$ & $2.6 \pm 0.4$ & $3.9 \pm 0.2$ & $4.0 \pm 0.6$ & $2.7 \pm 0.4$ \\
\hline & Freezer $^{\mathrm{b}}\left(-20^{\circ} \mathrm{C}\right)$ & $3.4 \pm 0.2$ & $4.7 \pm 0.4$ & $4.2 \pm 0.5$ & $4.8 \pm 0.4$ & $2.1 \pm 0.2$ & $2.7 \pm 0.7$ & $3.3 \pm 0.2$ & $3.8 \pm 0.3$ \\
\hline & Refrigerator ${ }^{\mathrm{b}}\left(4^{\circ} \mathrm{C}\right)$ & $3.1 \pm 0.5$ & $3.1 \pm 0.2$ & $3.2 \pm 0.4$ & $3.8 \pm 1.2$ & $2.1 \pm 0.2$ & $2.1 \pm 0.6$ & $2.4 \pm 0.5$ & $2.6 \pm 0.4$ \\
\hline & Room temperature ${ }^{\mathrm{b}}$ & $3.4 \pm 0.6$ & $4.2 \pm 0.5$ & $4.3 \pm 1.0$ & $4.4 \pm 0.5$ & $4.7 \pm 2.1$ & $2.9 \pm 0.6$ & $3.7 \pm 0.7$ & $3.5 \pm 0.4$ \\
\hline & Elevated temp $\mathrm{p}^{\mathrm{b}}\left(40^{\circ} \mathrm{C}\right)$ & $5.7 \pm 0.2$ & $6.8 \pm 1.3$ & $5.9 \pm 0.8$ & $6.7 \pm 1.9$ & $3.0 \pm 0.7$ & $3.8 \pm 0.7$ & $4.9 \pm 0.6$ & $5.0 \pm 0.5$ \\
\hline \multirow{5}{*}{ 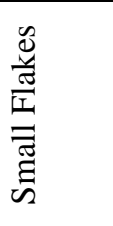 } & Control $^{\mathrm{a}}$ & $4.6 \pm 0.2$ & $4.8 \pm 0.4$ & $4.8 \pm 0.2$ & $4.7 \pm 0.4$ & $2.8 \pm 0.8$ & $3.6 \pm 0.6$ & $3.9 \pm 0.5$ & $3.1 \pm 0.7$ \\
\hline & Freezer $^{\mathrm{b}}\left(-20^{\circ} \mathrm{C}\right)$ & $3.0 \pm 0.3$ & $8.5 \pm 0.6$ & $3.8 \pm 0.1$ & $4.7 \pm 0.4$ & $2.2 \pm 0.3$ & $1.9 \pm 0.1$ & $2.8 \pm 0.8$ & $2.9 \pm 0.3$ \\
\hline & Refrigerator ${ }^{\mathrm{b}}\left(4^{\circ} \mathrm{C}\right)$ & $2.7 \pm 0.3$ & $3.5 \pm 0.3$ & $2.6 \pm 0.4$ & $4.5 \pm 0.6$ & $2.5 \pm 0.5$ & $2.0 \pm 0.2$ & $2.2 \pm 0.2$ & $1.7 \pm 0.3$ \\
\hline & Room temperature $^{b}$ & $4.2 \pm 0.4$ & $4.4 \pm 0.3$ & $3.6 \pm 0.4$ & $5.0 \pm 0.8$ & $2.7 \pm 1.2$ & $3.3 \pm 1.5$ & $2.5 \pm 0.6$ & $4.1 \pm 0.5$ \\
\hline & Elevated temp $p^{\mathrm{b}}\left(40^{\circ} \mathrm{C}\right)$ & $5.1 \pm 0.3$ & $6.6 \pm 0.7$ & $5.6 \pm 0.5$ & $7.3 \pm 0.5$ & $4.0 \pm 0.4$ & $6.8 \pm 1.2$ & $3.9 \pm 0.5$ & $4.1 \pm 1.3$ \\
\hline \multirow{5}{*}{$\begin{array}{l}\overline{0} \\
\overline{0} \\
0 \\
0 \\
0 \\
0 \\
0 \\
0 \\
0\end{array}$} & Control $^{\mathrm{a}}$ & $4.1 \pm 0.4$ & $4.3 \pm 0.7$ & $4.3 \pm 0.8$ & $3.8 \pm 0.3$ & $3.0 \pm 0.5$ & $3.4 \pm 0.3$ & $4.0 \pm 0.6$ & $3.2 \pm 0.3$ \\
\hline & Freezer $^{\mathrm{b}}\left(-20^{\circ} \mathrm{C}\right)$ & $4.2 \pm 0.6$ & $6.7 \pm 2.5$ & $5.6 \pm 0.7$ & $3.6 \pm 0.1$ & $1.9 \pm 0.1$ & $1.9 \pm 0.2$ & $2.3 \pm 0.5$ & $1.7 \pm 0.4$ \\
\hline & Refrigerator $^{\mathrm{b}}\left(4^{\circ} \mathrm{C}\right)$ & $3.4 \pm 0.6$ & $2.6 \pm 0.3$ & $3.2 \pm 0.3$ & $1.7 \pm 0.8$ & $1.6 \pm 0.95$ & $2.1 \pm 0.6$ & $2.4 \pm 0.3$ & $1.9 \pm 0.6$ \\
\hline & Room temperature $^{\mathrm{b}}$ & $2.6 \pm 0.5$ & $2.5 \pm 0.7$ & $3.2 \pm 0.5$ & $1.96 \pm 0.4$ & $2.4 \pm 1.3$ & $2.5 \pm 0.7$ & $4.2 \pm 1.8$ & $2.3 \pm 0.6$ \\
\hline & Elevated temp $p^{\mathrm{b}}\left(40^{\circ} \mathrm{C}\right)$ & $4.1 \pm 0.8$ & $3.6 \pm 0.9$ & $4.9 \pm 0.8$ & $3.9 \pm 0.6$ & $4.1 \pm 2.6$ & $2.7 \pm 0.4$ & $2.9 \pm 0.5$ & $2.9 \pm 1.0$ \\
\hline
\end{tabular}

${ }^{a}$ moisture content of samples before storage; ${ }^{b}$ moisture content of samples after 12 months of storage. Samples stored in freezer were packaged in glass bottles with plastic screw caps, and samples stored in refrigerator, at room temperature, and at elevated temperature were packaged in aluminum foil laminate packages.

*Particle size: Large flakes (LF): 0.85 - $1.18 \mathrm{~mm}$, Small flakes (SF): $0.71-1.0 \mathrm{~mm}$, Coarse Powder (CP): 0.25 - $0.5 \mathrm{~mm}$. 
Table S2. Effect of storage conditions on the color values of large flakes (dried at $40^{\circ} \mathrm{C}$ and/or liquid propane extracted).

\begin{tabular}{|c|c|c|c|c|c|c|c|c|c|c|c|c|c|c|c|c|c|c|c|c|}
\hline Extraction time (min) & \multicolumn{5}{|c|}{0} & \multicolumn{5}{|c|}{10} & \multicolumn{5}{|c|}{20} & \multicolumn{5}{|c|}{40} \\
\hline Storage temperature* $\left({ }^{\circ} \mathrm{C}\right)$ & $\mathrm{C}$ & $\mathrm{FR}^{\mathrm{a}}$ & $\mathrm{RF}^{\mathrm{b}}$ & $\mathrm{R}^{\mathrm{b}}$ & $\mathrm{ET}^{\mathrm{b}}$ & $\mathrm{C}$ & $\mathrm{FR}^{\mathrm{a}}$ & $\mathrm{RF}^{\mathrm{b}}$ & $\mathrm{R}^{\mathrm{b}}$ & $\mathrm{ET}^{\mathrm{b}}$ & $\mathrm{C}$ & $\mathrm{FR}^{\mathrm{a}}$ & $\mathrm{RF}^{\mathrm{b}}$ & $\mathrm{R}^{\mathrm{b}}$ & $\mathrm{ET}^{\mathrm{b}}$ & $\mathrm{C}$ & $\mathrm{FR}^{\mathrm{a}}$ & $\mathrm{RF}^{\mathrm{b}}$ & $\mathrm{R}^{\mathrm{b}}$ & $\mathrm{ET}^{\mathrm{b}}$ \\
\hline Storage time (months) & 0 & 12 & 12 & 12 & 12 & 0 & 12 & 12 & 12 & 12 & 0 & 12 & 12 & 12 & 12 & 0 & 12 & 12 & 12 & 12 \\
\hline L* (Lightness) & $46.9 \mathrm{a}$ & $46.0 \mathrm{a}$ & $45.7 \mathrm{a}$ & $46.1 \mathrm{a}$ & $42.7 \mathrm{~b}$ & $47.6 \mathrm{a}$ & $47.9 \mathrm{a}$ & $46.4 \mathrm{a}$ & $46.7 \mathrm{a}$ & $43.5 \mathrm{~b}$ & $48.3 \mathrm{a}$ & $48.3 \mathrm{a}$ & $46.4 \mathrm{a}$ & $46.3 \mathrm{a}$ & $43.3 b$ & $47.7 \mathrm{a}$ & $49.4 \mathrm{a}$ & $47.4 \mathrm{a}$ & $44.9 \mathrm{~b}$ & $42.9 b$ \\
\hline$a^{*}$ (greenness) & -12.4 & $-12.4 \mathrm{a}$ & $-12.2 \mathrm{a}$ & $-9.2 b$ & $-0.9 \mathrm{c}$ & $-12.3 \mathrm{a}$ & $-12.2 \mathrm{ab}$ & $-11.5 b$ & $-10.6 c$ & $-0.6 \mathrm{~d}$ & $-12.3 \mathrm{a}$ & $-12.4 \mathrm{a}$ & $-12.1 \mathrm{a}$ & $-9.7 b$ & $-0.7 \mathrm{c}$ & $-12.4 \mathrm{a}$ & $-11.7 \mathrm{ab}$ & $-10.8 b$ & $-8.6 c$ & $-1.0 \mathrm{~d}$ \\
\hline b* (yellowness) & $25.0 \mathrm{a}$ & $23.5 \mathrm{ab}$ & $24.1 \mathrm{ab}$ & $23.5 b$ & $24.7 \mathrm{ab}$ & $23.6 \mathrm{a}$ & $22.7 \mathrm{ab}$ & $22.1 \mathrm{~b}$ & $22.1 \mathrm{~b}$ & $22.8 \mathrm{ab}$ & $23.3 \mathrm{a}$ & $22.4 \mathrm{ab}$ & $21.9 \mathrm{bc}$ & $21.4 \mathrm{c}$ & $24.0 \mathrm{a}$ & $23.6 \mathrm{a}$ & $23.8 \mathrm{ab}$ & $22.3 b$ & $22.3 b$ & $24.4 \mathrm{a}$ \\
\hline Chroma & $27.9 \mathrm{a}$ & $26.6 \mathrm{ab}$ & $27.0 \mathrm{a}$ & $25.3 b$ & $25.1 \mathrm{~b}$ & $26.6 \mathrm{a}$ & $25.7 \mathrm{ab}$ & $24.9 \mathrm{~b}$ & $24.5 \mathrm{~b}$ & $22.8 \mathrm{c}$ & $26.3 \mathrm{a}$ & $25.6 \mathrm{ab}$ & $25.1 \mathrm{~b}$ & $23.5 \mathrm{c}$ & $24.0 \mathrm{c}$ & $26.6 \mathrm{a}$ & $26.5 \mathrm{ab}$ & $24.8 \mathrm{bc}$ & $23.9 \mathrm{c}$ & $24.4 \mathrm{c}$ \\
\hline Hue Angle & 178.9 & $178.9 \mathrm{~b}$ & $178.9 \mathrm{bc}$ & $178.8 \mathrm{bc}$ & $180.3 \mathrm{a}$ & $178.9 \mathrm{~b}$ & $178.2 b$ & $178.9 \mathrm{~b}$ & $178.9 \mathrm{~b}$ & $180.3 \mathrm{a}$ & $178.9 \mathrm{~b}$ & $178.9 \mathrm{ab}$ & $178.9 \mathrm{~b}$ & $178.9 \mathrm{~b}$ & $179.6 \mathrm{a}$ & $178.9 \mathrm{a}$ & $178.9 \mathrm{a}$ & $178.9 \mathrm{a}$ & $178.8 \mathrm{a}$ & $180.9 b$ \\
\hline Browning Index (BI) & 49.4 & $44.8 \mathrm{~b}$ & $48.1 \mathrm{~b}$ & $50.9 \mathrm{~b}$ & $81.4 \mathrm{a}$ & $43.1 \mathrm{~b}$ & $39.7 \mathrm{~b}$ & $40.7 \mathrm{~b}$ & $41.9 \mathrm{~b}$ & $69.9 \mathrm{a}$ & $41.2 \mathrm{~b}$ & $37.7 \mathrm{~b}$ & $38.9 \mathrm{~b}$ & $41.9 \mathrm{~b}$ & $75.5 \mathrm{a}$ & $42.8 \mathrm{~b}$ & $42.6 \mathrm{~b}$ & $41.8 \mathrm{~b}$ & $48.3 \mathrm{a}$ & $77.5 \mathrm{a}$ \\
\hline
\end{tabular}

*C: Control; FR: Freezer, RF: Refrigerator, R: Room temperature, ET: Elevated temperature. a, b, c, d, e denote significantly different color values (at 0.05 probability level) between control samples, samples stored in freezer, in refrigerator, at room temperature and at elevated temperature. ${ }^{\text {a }}$ Samples stored in freezer were packaged in glass bottles with plastic screw caps. ${ }^{\mathrm{b}}$ samples stored in refrigerator, at room temperature, and at elevated temperature were packaged in aluminum foil laminate packages. 
Table S3. Effect of storage conditions on the color values of large flakes (dried at $60^{\circ} \mathrm{C}$ and/or liquid propane extracted).

\begin{tabular}{|c|c|c|c|c|c|c|c|c|c|c|c|c|c|c|c|c|c|c|c|c|}
\hline Extraction time (min) & \multicolumn{5}{|c|}{0} & \multicolumn{5}{|c|}{10} & \multicolumn{5}{|c|}{20} & \multicolumn{5}{|c|}{40} \\
\hline Storage temperature $*\left({ }^{\circ} \mathrm{C}\right)$ & $\mathrm{C}$ & $\mathrm{FR}^{\mathrm{a}}$ & $\mathrm{RF}^{\mathrm{b}}$ & $\mathrm{R}^{\mathrm{b}}$ & $\mathrm{ET}^{\mathrm{b}}$ & $\mathrm{C}$ & $\mathrm{FR}^{\mathrm{a}}$ & $\mathrm{RF}^{\mathrm{b}}$ & $\mathrm{R}^{\mathrm{b}}$ & $\mathrm{ET}^{\mathrm{b}}$ & $\mathrm{C}$ & $\mathrm{FR}^{\mathrm{a}}$ & $\mathrm{RF}^{\mathrm{b}}$ & $\mathrm{R}^{\mathrm{b}}$ & $\mathrm{ET}^{\mathrm{b}}$ & $\mathrm{C}$ & $\mathrm{FR}^{\mathrm{a}}$ & $\mathrm{RF}^{\mathrm{b}}$ & $\mathrm{R}^{\mathrm{b}}$ & $\mathrm{ET}^{\mathrm{b}}$ \\
\hline Storage time (months) & 0 & 12 & 12 & 12 & 12 & 0 & 12 & 12 & 12 & 12 & 0 & 12 & 12 & 12 & 12 & 0 & 12 & 12 & 12 & 12 \\
\hline L* (Lightness) & $46.4 \mathrm{a}$ & $45.9 \mathrm{a}$ & $43.9 \mathrm{a}$ & $44.2 \mathrm{a}$ & $44.6 \mathrm{a}$ & $47.6 \mathrm{ab}$ & $48.3 \mathrm{ab}$ & $45.5 \mathrm{c}$ & $44.5 \mathrm{c}$ & $45.9 \mathrm{bc}$ & $47.6 \mathrm{a}$ & $45.8 \mathrm{abc}$ & $43.8 \mathrm{c}$ & $45.1 \mathrm{bc}$ & $45.9 \mathrm{ab}$ & $48.3 \mathrm{ab}$ & $44.1 \mathrm{c}$ & $45.9 \mathrm{bc}$ & $43.5 \mathrm{c}$ & $44.3 \mathrm{c}$ \\
\hline a* (greenness) & $-13.1 \mathrm{a}$ & $-13.0 \mathrm{a}$ & $-11.8 b$ & $-10.5 c$ & $-3.7 d$ & $-13.4 \mathrm{a}$ & $-11.9 b c$ & $-12.5 b c$ & $-10.9 c$ & $-3.4 \mathrm{~d}$ & $-12.8 \mathrm{a}$ & $-12.3 a b$ & $-11.9 \mathrm{~b}$ & $-10.8 \mathrm{c}$ & $-2.1 d$ & $-12.7 \mathrm{a}$ & $-10.0 b$ & $-11.5 c$ & $-10.3 b$ & $-1.9 \mathrm{~d}$ \\
\hline$b^{*}$ (yellowness) & $24.9 \mathrm{a}$ & $23.4 \mathrm{ab}$ & $22.6 \mathrm{~b}$ & $21.9 \mathrm{~b}$ & $22.4 b$ & $23.7 \mathrm{a}$ & $22.2 b$ & $21.9 \mathrm{~b}$ & $19.9 \mathrm{c}$ & $22.4 \mathrm{~b}$ & $23.3 \mathrm{a}$ & $22.0 \mathrm{abc}$ & $21.3 \mathrm{bc}$ & $20.7 \mathrm{c}$ & $21.9 \mathrm{~b}$ & $22.9 \mathrm{a}$ & $20.7 b c$ & $21.4 b$ & $19.8 \mathrm{c}$ & $20.9 \mathrm{~b}$ \\
\hline Chroma & $28.2 \mathrm{a}$ & $26.8 \mathrm{ab}$ & $25.5 b$ & $24.3 \mathrm{bc}$ & $22.7 \mathrm{c}$ & $27.2 \mathrm{a}$ & $25.2 \mathrm{~b}$ & $25.3 \mathrm{~b}$ & $22.7 \mathrm{c}$ & $22.7 \mathrm{c}$ & 26.6a & $24.8 \mathrm{ab}$ & $24.4 \mathrm{~b}$ & $23.4 \mathrm{~b}$ & $21.9 \mathrm{c}$ & $26.3 \mathrm{a}$ & $23.0 \mathrm{bc}$ & $24.3 b$ & $22.3 \mathrm{c}$ & $21.1 \mathrm{~d}$ \\
\hline Hue Angle & $178.9 \mathrm{ab}$ & $178.9 \mathrm{ab}$ & $178.9 \mathrm{ab}$ & $179.3 \mathrm{a}$ & $178.6 \mathrm{~b}$ & $178.9 \mathrm{a}$ & $178.9 \mathrm{a}$ & $178.9 \mathrm{a}$ & $178.9 \mathrm{a}$ & $178.6 \mathrm{~b}$ & 178.9ab & $178.9 \mathrm{ab}$ & $178.9 \mathrm{a}$ & $178.9 \mathrm{~b}$ & $178.5 \mathrm{c}$ & $178.9 \mathrm{a}$ & $178.9 \mathrm{~b}$ & $178.9 \mathrm{a}$ & $178.9 \mathrm{ab}$ & $178.5 \mathrm{c}$ \\
\hline Browning Index (BI) & $48.5 b$ & $43.4 \mathrm{c}$ & $45.4 \mathrm{bc}$ & $46.2 b c$ & $59.9 \mathrm{a}$ & $41.2 \mathrm{~b}$ & $38.0 \mathrm{bc}$ & $39.5 \mathrm{~b}$ & $35.9 \mathrm{c}$ & $57.4 \mathrm{a}$ & $40.9 b$ & $38.2 \mathrm{~b}$ & $40.2 b$ & $38.5 b$ & $56.9 \mathrm{a}$ & $39.2 \mathrm{~b}$ & $41.9 b$ & $38.7 b$ & $38.3 b$ & $58.1 \mathrm{a}$ \\
\hline
\end{tabular}

*C: Control; FR: Freezer, RF: Refrigerator, R: Room temperature, ET: Elevated temperature. a, b, c, d, e denote significantly different color values (at 0.05 probability level) between control samples, samples stored in freezer, in refrigerator, at room temperature and at elevated temperature. ${ }^{a}$ Samples stored in freezer were packaged in glass bottles with plastic screw caps. ${ }^{b}$ samples stored in refrigerator, at room temperature, and at elevated temperature were packaged in aluminum foil laminate packages. 
Table S4. Effect of storage conditions on the color values of small flakes (dried at $40^{\circ} \mathrm{C}$ and/or liquid propane extracted).

\begin{tabular}{|c|c|c|c|c|c|c|c|c|c|c|c|c|c|c|c|c|c|c|c|c|}
\hline Extraction time (min) & \multicolumn{5}{|c|}{0} & \multicolumn{5}{|c|}{10} & \multicolumn{5}{|c|}{20} & \multicolumn{5}{|c|}{40} \\
\hline Storage temperature* $\left({ }^{\circ} \mathrm{C}\right)$ & $\mathrm{C}$ & $\mathrm{FR}^{\mathrm{a}}$ & $\mathrm{RF}^{\mathrm{b}}$ & $\mathrm{R}^{\mathrm{b}}$ & $\mathrm{ET}^{\mathrm{b}}$ & $\mathrm{C}$ & $\mathrm{FR}^{\mathrm{a}}$ & $\mathrm{RF}^{\mathrm{b}}$ & $\mathrm{R}^{\mathrm{b}}$ & $\mathrm{ET}^{\mathrm{b}}$ & $\mathrm{C}$ & $\mathrm{FR}^{\mathrm{a}}$ & $\mathrm{RF}^{\mathrm{b}}$ & $\mathrm{R}^{\mathrm{b}}$ & $\mathrm{ET}^{\mathrm{b}}$ & $\mathrm{C}$ & $\mathrm{FR}^{\mathrm{a}}$ & $\mathrm{RF}^{\mathrm{b}}$ & $\mathrm{R}^{\mathrm{b}}$ & $\mathrm{ET}^{\mathrm{b}}$ \\
\hline Storage time (months) & 0 & 12 & 12 & 12 & 12 & 0 & 12 & 12 & 12 & 12 & 0 & 12 & 12 & 12 & 12 & 0 & 12 & 12 & 12 & 12 \\
\hline L* (Lightness) $^{*}$ & $47.6 \mathrm{~b}$ & $50.7 \mathrm{a}$ & $44.8 \mathrm{c}$ & $46.7 \mathrm{~b}$ & $44.9 \mathrm{c}$ & $48.7 \mathrm{a}$ & $49.8 \mathrm{a}$ & $45.8 \mathrm{~b}$ & $46.2 \mathrm{~b}$ & $44.9 \mathrm{~b}$ & $48.9 \mathrm{~b}$ & $52.9 \mathrm{a}$ & $45.5 \mathrm{~d}$ & $47.4 \mathrm{c}$ & $45.4 \mathrm{~d}$ & $48.0 \mathrm{~b}$ & $51.9 \mathrm{a}$ & $45.0 \mathrm{c}$ & $47.1 \mathrm{~b}$ & $45.1 \mathrm{c}$ \\
\hline$a^{*}$ (greenness) & $-12.7 \mathrm{a}$ & $-13.3 a$ & $-12.6 a$ & $-10.2 b$ & $-1.1 \mathrm{c}$ & $-12.9 \mathrm{a}$ & $-12.9 \mathrm{a}$ & $-12.3 b$ & $-9.6 c$ & $-0.8 \mathrm{~d}$ & $-12.2 b$ & $-13.9 \mathrm{a}$ & $-12.4 b$ & $-9.7 \mathrm{c}$ & $-0.8 \mathrm{~d}$ & $-13.3 \mathrm{a}$ & $-13.5 \mathrm{a}$ & $-11.8 b$ & $-9.4 c$ & $-0.5 \mathrm{~d}$ \\
\hline$b *$ (yellowness) & $25.1 \mathrm{~b}$ & $26.4 \mathrm{ab}$ & $22.5 \mathrm{c}$ & $23.2 \mathrm{c}$ & $26.1 \mathrm{a}$ & $24.7 \mathrm{a}$ & $24.9 \mathrm{a}$ & $23.2 \mathrm{~b}$ & $22.5 b$ & $25.5 \mathrm{a}$ & $24.6 b$ & $23.4 \mathrm{c}$ & $23.3 \mathrm{c}$ & $23.6 \mathrm{c}$ & $27.6 \mathrm{a}$ & $23.9 \mathrm{~b}$ & $23.1 \mathrm{bc}$ & $21.5 \mathrm{~d}$ & $22.5 \mathrm{c}$ & $26.0 \mathrm{a}$ \\
\hline Chroma & $28.1 \mathrm{a}$ & $29.5 \mathrm{a}$ & $25.8 \mathrm{~b}$ & $25.3 \mathrm{~b}$ & $26.2 b$ & $27.9 \mathrm{a}$ & $28.1 \mathrm{a}$ & $26.3 b$ & $24.5 \mathrm{~d}$ & $25.5 b$ & $27.5 \mathrm{a}$ & $27.2 \mathrm{a}$ & $26.4 \mathrm{~b}$ & $25.6 \mathrm{c}$ & $27.6 \mathrm{a}$ & $27.4 \mathrm{a}$ & $26.8 \mathrm{ab}$ & $24.5 \mathrm{c}$ & $24.4 \mathrm{c}$ & $26.0 \mathrm{~b}$ \\
\hline Hue Angle & $178.9 \mathrm{a}$ & $178.9 \mathrm{a}$ & $178.9 \mathrm{a}$ & $178.8 \mathrm{a}$ & $178.8 \mathrm{a}$ & $178.9 \mathrm{~b}$ & $178.7 \mathrm{ab}$ & $178.9 \mathrm{~b}$ & $178.8 \mathrm{~b}$ & $179.5 \mathrm{a}$ & $178.9 \mathrm{c}$ & $178.9 \mathrm{a}$ & $178.9 \mathrm{~b}$ & $178.8 \mathrm{~d}$ & $178.5 \mathrm{e}$ & $178.9 \mathrm{a}$ & $178.9 \mathrm{ab}$ & $178.9 \mathrm{ab}$ & $178.8 \mathrm{a}$ & $179.5 b$ \\
\hline Browning Index (BI) & $47.8 \mathrm{~b}$ & $47.0 \mathrm{~b}$ & $42.3 b$ & $46.8 \mathrm{~b}$ & $79.9 \mathrm{a}$ & $44.2 b$ & $43.8 b$ & $44.0 \mathrm{~b}$ & $46.1 \mathrm{~b}$ & $77.7 \mathrm{a}$ & $45.1 \mathrm{c}$ & $33.7 \mathrm{~d}$ & $44.6 \mathrm{c}$ & $48.4 \mathrm{~b}$ & $85.9 \mathrm{a}$ & $41.9 b$ & $34.5 \mathrm{~d}$ & $39.6 c$ & $45.4 b$ & $80.2 \mathrm{a}$ \\
\hline
\end{tabular}

${ }^{*} \mathrm{C}$ : Control; FR: Freezer, RF: Refrigerator, R: Room temperature, ET: Elevated temperature. a, b, c, d, e denote significantly different color values (at 0.05 probability level) between control samples, samples stored in freezer, in refrigerator, at room temperature and at elevated temperature. ${ }^{a}$ Samples stored in freezer were packaged in glass bottles with plastic screw caps. ${ }^{\text {b }}$ samples stored in refrigerator, at room temperature, and at elevated temperature were packaged in aluminum foil laminate packages. 
Table S5. Effect of storage conditions on the color values of small flakes (dried at $60^{\circ} \mathrm{C}$ and/or liquid propane extracted).

\begin{tabular}{|c|c|c|c|c|c|c|c|c|c|c|c|c|c|c|c|c|c|c|c|c|}
\hline Extraction time (min) & \multicolumn{5}{|c|}{0} & \multicolumn{5}{|c|}{10} & \multicolumn{5}{|c|}{20} & \multicolumn{5}{|c|}{40} \\
\hline Storage temperature $*\left({ }^{\circ} \mathrm{C}\right)$ & $\mathrm{C}$ & $\mathrm{FR}^{\mathrm{a}}$ & $\mathrm{RF}^{\mathrm{b}}$ & $\mathrm{R}^{\mathrm{b}}$ & $\mathrm{ET}^{\mathrm{b}}$ & $\mathrm{C}$ & $\mathrm{FR}^{\mathrm{a}}$ & $\mathrm{RF}^{\mathrm{b}}$ & $\mathrm{R}^{\mathrm{b}}$ & $\mathrm{ET}^{\mathrm{b}}$ & $\mathrm{C}$ & $\mathrm{FR}^{\mathrm{a}}$ & $\mathrm{RF}^{\mathrm{b}}$ & $\mathrm{R}^{\mathrm{b}}$ & $\mathrm{ET}^{\mathrm{b}}$ & $\mathrm{C}$ & $\mathrm{FR}^{\mathrm{a}}$ & $\mathrm{RF}^{\mathrm{b}}$ & $\mathrm{R}^{\mathrm{b}}$ & $\mathrm{ET}^{\mathrm{b}}$ \\
\hline Storage time (months) & 0 & 12 & 12 & 12 & 12 & 0 & 12 & 12 & 12 & 12 & 0 & 12 & 12 & 12 & 12 & 0 & 12 & 12 & 12 & 12 \\
\hline L* (Lightness) & $46.9 \mathrm{a}$ & $47.7 \mathrm{a}$ & $44.2 \mathrm{c}$ & $45.5 b$ & $42.7 \mathrm{~d}$ & $45.8 \mathrm{a}$ & $47.7 \mathrm{a}$ & $44.2 \mathrm{a}$ & $44.9 \mathrm{a}$ & $40.9 \mathrm{~b}$ & $45.6 \mathrm{~b}$ & $48.1 \mathrm{a}$ & $44.4 \mathrm{bc}$ & $43.2 \mathrm{c}$ & $43.7 \mathrm{c}$ & $47.3 \mathrm{a}$ & $47.6 \mathrm{a}$ & $44.8 \mathrm{~b}$ & $45.6 \mathrm{ab}$ & $45.1 \mathrm{~b}$ \\
\hline$a^{*}$ (greenness) & $-13.0 \mathrm{a}$ & $-13.5 \mathrm{a}$ & $-11.9 b$ & $-10.6 c$ & $-2.5 \mathrm{~d}$ & $-13.6 a$ & $-13.4 \mathrm{a}$ & $-12.3 b$ & $-10.9 c$ & $-1.7 \mathrm{~d}$ & $-13.3 \mathrm{a}$ & $-13.8 \mathrm{a}$ & $-12.9 b$ & $-11.1 \mathrm{c}$ & $-3.4 \mathrm{~d}$ & $-12.9 \mathrm{a}$ & $-13.1 \mathrm{a}$ & $-12.7 \mathrm{a}$ & $-9.7 b$ & $-2.4 \mathrm{c}$ \\
\hline$b^{*}$ (yellowness) & $25.3 \mathrm{a}$ & $24.5 \mathrm{a}$ & $22.6 \mathrm{~b}$ & $21.2 \mathrm{c}$ & $22.3 b$ & $23.4 \mathrm{a}$ & $23.3 \mathrm{a}$ & $21.5 b$ & $20.6 \mathrm{~d}$ & $20.3 \mathrm{~d}$ & $22.7 b$ & $22.5 \mathrm{abc}$ & $21.7 \mathrm{c}$ & $19.8 \mathrm{~d}$ & $23.5 \mathrm{~d}$ & $23.2 \mathrm{a}$ & $22.1 \mathrm{a}$ & $21.8 \mathrm{~b}$ & $20.6 \mathrm{c}$ & $23.3 \mathrm{a}$ \\
\hline Chroma & $28.5 \mathrm{a}$ & $28.0 \mathrm{a}$ & $25.6 \mathrm{~b}$ & $23.7 \mathrm{c}$ & $22.5 \mathrm{~d}$ & $27.0 \mathrm{a}$ & $26.8 \mathrm{a}$ & $24.7 b$ & $23.3 \mathrm{c}$ & $20.4 \mathrm{~d}$ & $26.3 \mathrm{a}$ & $26.3 \mathrm{ab}$ & $25.3 b$ & $22.7 d$ & $23.8 \mathrm{c}$ & $26.4 \mathrm{a}$ & $25.7 \mathrm{ab}$ & $25.2 \mathrm{~b}$ & $22.8 \mathrm{c}$ & $23.4 \mathrm{c}$ \\
\hline Hue Angle & $178.9 \mathrm{ab}$ & $178.9 \mathrm{a}$ & $178.9 \mathrm{ab}$ & $178.9 \mathrm{~b}$ & $178.5 \mathrm{c}$ & $178.9 \mathrm{~b}$ & $178.9 \mathrm{ab}$ & $178.9 \mathrm{~b}$ & $178.9 \mathrm{~b}$ & $179.5 \mathrm{a}$ & $178.9 \mathrm{a}$ & $178.9 \mathrm{a}$ & $178.9 \mathrm{a}$ & $178.9 \mathrm{~b}$ & $178.6 \mathrm{c}$ & $178.9 \mathrm{a}$ & $178.9 \mathrm{a}$ & $178.9 \mathrm{a}$ & $178.9 \mathrm{~b}$ & $178.5 \mathrm{c}$ \\
\hline Browning Index (BI) & $49.2 \mathrm{~b}$ & $43.8 \mathrm{c}$ & $44.8 \mathrm{c}$ & $40.1 \mathrm{~d}$ & $65.9 \mathrm{a}$ & $42.1 \mathrm{~b}$ & $39.6 \mathrm{~b}$ & $39.6 \mathrm{~b}$ & $37.9 \mathrm{~b}$ & $63.8 \mathrm{a}$ & $40.6 \mathrm{~b}$ & $35.5 \mathrm{c}$ & $38.9 \mathrm{~b}$ & $37.0 \mathrm{c}$ & $67.1 \mathrm{a}$ & $40.5 b$ & $36.3 \mathrm{~b}$ & $38.9 \mathrm{~b}$ & $39.9 \mathrm{~b}$ & $65.9 \mathrm{a}$ \\
\hline
\end{tabular}

*C: Control; FR: Freezer, RF: Refrigerator, R: Room temperature, ET: Elevated temperature. a, b, c, d, e denote significantly different color values (at 0.05 probability level) between control samples, samples stored in freezer, in refrigerator, at room temperature and at elevated temperature. ${ }^{a}$ Samples stored in freezer were packaged in glass bottles with plastic screw caps. ${ }^{\mathrm{b}}$ samples stored in refrigerator, at room temperature, and at elevated temperature were packaged in aluminum foil laminate packages. 
Table S6. Effect of storage conditions on the color values of coarse powder (dried at $40^{\circ} \mathrm{C}$ and/or liquid propane extracted).

\begin{tabular}{|c|c|c|c|c|c|c|c|c|c|c|c|c|c|c|c|c|c|c|c|c|}
\hline Extraction time (min) & \multicolumn{5}{|c|}{0} & \multicolumn{5}{|c|}{10} & \multicolumn{5}{|c|}{20} & \multicolumn{5}{|c|}{40} \\
\hline Storage temperature* $\left({ }^{\circ} \mathrm{C}\right)$ & $\mathrm{C}$ & $\mathrm{FR}^{\mathrm{a}}$ & $\mathrm{RF}^{\mathrm{b}}$ & $\mathrm{R}^{\mathrm{b}}$ & $\mathrm{ET}^{\mathrm{b}}$ & $\mathrm{C}$ & $\mathrm{FR}^{\mathrm{a}}$ & $\mathrm{RF}^{\mathrm{b}}$ & $\mathrm{R}^{\mathrm{b}}$ & $\mathrm{ET}^{\mathrm{b}}$ & $\mathrm{C}$ & $\mathrm{FR}^{\mathrm{a}}$ & $\mathrm{RF}^{\mathrm{b}}$ & $\mathrm{R}^{\mathrm{b}}$ & $\mathrm{ET}^{\mathrm{b}}$ & $\mathrm{C}$ & $\mathrm{FR}^{\mathrm{a}}$ & $\mathrm{RF}^{\mathrm{b}}$ & $\mathrm{R}^{\mathrm{b}}$ & $\mathrm{ET}^{\mathrm{b}}$ \\
\hline Storage time (months) & 0 & 12 & 12 & 12 & 12 & 0 & 12 & 12 & 12 & 12 & 0 & 12 & 12 & 12 & 12 & 0 & 12 & 12 & 12 & 12 \\
\hline L* (Lightness) & $46.5 \mathrm{~b}$ & $48.6 \mathrm{a}$ & $46.4 \mathrm{~b}$ & $47.4 \mathrm{ab}$ & $44.8 \mathrm{c}$ & $47.5 \mathrm{a}$ & $47.9 \mathrm{a}$ & $47.5 \mathrm{a}$ & $46.9 \mathrm{a}$ & $45.3 \mathrm{~b}$ & $47.8 \mathrm{a}$ & $47.4 \mathrm{a}$ & $48.2 \mathrm{a}$ & $46.1 \mathrm{~b}$ & $45.2 \mathrm{bc}$ & $50.0 \mathrm{a}$ & $49.5 \mathrm{~b}$ & $49.8 \mathrm{~b}$ & $49.2 \mathrm{~b}$ & $47.4 \mathrm{c}$ \\
\hline $\mathrm{a}^{*}$ (greenness) & $-12.8 b$ & $-13.7 \mathrm{a}$ & $-12.4 b$ & $-11.1 \mathrm{c}$ & $-2.1 d$ & $-13.1 b$ & $-13.5 \mathrm{a}$ & $-12.8 b$ & $-11.6 c$ & $-2.1 \mathrm{~d}$ & $-13.5 \mathrm{a}$ & $-13.3 \mathrm{ab}$ & $-12.8 b$ & $-10.8 c$ & $-0.7 d$ & $-12.6 a$ & $-12.6 \mathrm{a}$ & $-12.4 \mathrm{a}$ & $-10.5 \mathrm{ab}$ & $-1.4 c$ \\
\hline b* (yellowness) & $25.1 \mathrm{ab}$ & $25.5 \mathrm{~b}$ & $24.3 \mathrm{a}$ & $23.3 \mathrm{~d}$ & $25.0 \mathrm{ab}$ & $23.9 \mathrm{~b}$ & $23.9 b$ & $23.1 \mathrm{c}$ & $22.1 \mathrm{~d}$ & $24.9 \mathrm{a}$ & $24.1 \mathrm{~b}$ & $22.9 \mathrm{~d}$ & $23.1 \mathrm{c}$ & $22.1 \mathrm{~d}$ & $24.6 \mathrm{a}$ & $25.1 \mathrm{a}$ & $23.9 b$ & $24.0 \mathrm{~b}$ & $22.9 \mathrm{c}$ & $25.6 \mathrm{a}$ \\
\hline Chroma & $28.2 \mathrm{~b}$ & $28.9 \mathrm{a}$ & $27.3 b$ & $25.8 \mathrm{~d}$ & $25.1 \mathrm{~d}$ & $27.3 \mathrm{a}$ & $27.4 \mathrm{a}$ & $26.4 \mathrm{~b}$ & $24.9 \mathrm{c}$ & $24.9 \mathrm{c}$ & $27.6 \mathrm{a}$ & $26.5 b$ & $26.4 \mathrm{~b}$ & $24.6 \mathrm{c}$ & $24.6 \mathrm{c}$ & $28.2 \mathrm{a}$ & $27.2 \mathrm{ab}$ & $27.1 \mathrm{~b}$ & $25.3 \mathrm{c}$ & $25.6 \mathrm{c}$ \\
\hline Hue Angle & $178.9 \mathrm{~b}$ & $178.9 \mathrm{a}$ & $178.9 \mathrm{~b}$ & $178.9 \mathrm{c}$ & $178.5 \mathrm{~d}$ & $178.9 \mathrm{a}$ & $178.9 \mathrm{a}$ & $178.9 \mathrm{a}$ & $178.9 \mathrm{~b}$ & $178.5 \mathrm{c}$ & $178.9 \mathrm{a}$ & $178.9 \mathrm{a}$ & $178.9 \mathrm{a}$ & $178.9 \mathrm{~b}$ & $178.5 \mathrm{c}$ & $178.9 \mathrm{~b}$ & $178.9 \mathrm{a}$ & $178.9 \mathrm{ab}$ & $178.9 \mathrm{c}$ & $178.5 \mathrm{~d}$ \\
\hline Browning Index (BI) & $49.5 \mathrm{~b}$ & $46.2 \mathrm{bc}$ & $47.0 \mathrm{bc}$ & $44.6 \mathrm{c}$ & $73.8 \mathrm{a}$ & $43.0 \mathrm{~b}$ & $41.2 \mathrm{bc}$ & $40.3 \mathrm{~cd}$ & $39.7 \mathrm{~d}$ & $71.7 \mathrm{a}$ & $42.2 \mathrm{~b}$ & $38.8 \mathrm{c}$ & $39.4 \mathrm{c}$ & $42.5 b$ & 73.1a & $44.8 \mathrm{~b}$ & $41.1 \mathrm{c}$ & $41.7 \mathrm{c}$ & $42.1 \mathrm{c}$ & $71.5 \mathrm{a}$ \\
\hline
\end{tabular}

*C: Control; FR: Freezer, RF: Refrigerator, R: Room temperature, ET: Elevated temperature. a, b, c, d, e denote significantly different color values (at 0.05 probability level) between control samples, samples stored in freezer, in refrigerator, at room temperature and at elevated temperature. ${ }^{a}$ Samples stored in freezer were packaged in glass bottles with plastic screw caps. ${ }^{b}$ samples stored in refrigerator, at room temperature, and at elevated temperature were packaged in aluminum foil laminate packages. 
Table S7. Effect of storage conditions on the color values of coarse powder (dried at $60^{\circ} \mathrm{C}$ and/or liquid propane extracted).

\begin{tabular}{|c|c|c|c|c|c|c|c|c|c|c|c|c|c|c|c|c|c|c|c|c|}
\hline Extraction time (min) & \multicolumn{5}{|c|}{0} & \multicolumn{5}{|c|}{10} & \multicolumn{5}{|c|}{20} & \multicolumn{5}{|c|}{40} \\
\hline Storage temperature $*\left({ }^{\circ} \mathrm{C}\right)$ & $\mathrm{C}$ & $\mathrm{FR}^{\mathrm{a}}$ & $\mathrm{RF}^{\mathrm{b}}$ & $\mathrm{R}^{\mathrm{b}}$ & $\mathrm{ET}^{\mathrm{b}}$ & $\mathrm{C}$ & $\mathrm{FR}^{\mathrm{a}}$ & $\mathrm{RF}^{\mathrm{b}}$ & $\mathrm{R}^{\mathrm{b}}$ & $\mathrm{ET}^{\mathrm{b}}$ & $\mathrm{C}$ & $\mathrm{FR}^{\mathrm{a}}$ & $\mathrm{RF}^{\mathrm{b}}$ & $\mathrm{R}^{\mathrm{b}}$ & $\mathrm{ET}^{\mathrm{b}}$ & $\mathrm{C}$ & $\mathrm{FR}^{\mathrm{a}}$ & $\mathrm{RF}^{\mathrm{b}}$ & $\mathrm{R}^{\mathrm{b}}$ & $\mathrm{ET}^{\mathrm{b}}$ \\
\hline Storage time (months) & 0 & 12 & 12 & 12 & 12 & 0 & 12 & 12 & 12 & 12 & 0 & 12 & 12 & 12 & 12 & 0 & 12 & 12 & 12 & 12 \\
\hline L* (Lightness) & $50.2 \mathrm{ab}$ & $52.2 \mathrm{ab}$ & $47.3 \mathrm{c}$ & $48.5 \mathrm{bc}$ & $47.4 \mathrm{c}$ & $46.4 \mathrm{~b}$ & $48.5 \mathrm{a}$ & $46.7 \mathrm{~b}$ & $45.9 \mathrm{~b}$ & $45.8 \mathrm{~b}$ & $46.9 \mathrm{a}$ & $47.1 \mathrm{a}$ & $45.9 \mathrm{a}$ & $46.1 \mathrm{a}$ & $44.3 b$ & $46.4 \mathrm{ab}$ & $47.9 \mathrm{a}$ & $46.6 \mathrm{ab}$ & $46.4 \mathrm{ab}$ & $45.6 \mathrm{~b}$ \\
\hline$a^{*}$ (greenness) & $-14.1 \mathrm{a}$ & $-15.1 b$ & $-13.5 c$ & $-11.7 d$ & $-3.4 \mathrm{e}$ & $-13.7 \mathrm{a}$ & $-13.9 \mathrm{a}$ & $-13.2 b$ & $-11.8 \mathrm{c}$ & $-4.1 \mathrm{~d}$ & $-12.7 \mathrm{a}$ & $-13.0 \mathrm{a}$ & $-12.4 \mathrm{a}$ & $-9.4 b$ & $-2.6 c$ & $-13.7 \mathrm{a}$ & $-14.1 b$ & $-13.1 c$ & $-11.9 \mathrm{~d}$ & $-3.8 \mathrm{e}$ \\
\hline$b^{*}$ (yellowness) & $26.9 \mathrm{~b}$ & 27.6a & $25.2 \mathrm{c}$ & $23.4 \mathrm{~d}$ & $25.5 \mathrm{c}$ & $23.5 \mathrm{~b}$ & $23.4 \mathrm{~b}$ & $22.4 \mathrm{c}$ & $20.8 \mathrm{~d}$ & $24.5 \mathrm{a}$ & $23.7 \mathrm{a}$ & $22.9 \mathrm{~b}$ & $22.1 \mathrm{c}$ & $22.2 \mathrm{c}$ & $23.5 \mathrm{ab}$ & $23.3 \mathrm{a}$ & $22.9 \mathrm{a}$ & $22.2 b$ & $21.2 \mathrm{c}$ & $23.2 \mathrm{a}$ \\
\hline Chroma & $30.4 \mathrm{~b}$ & $31.5 \mathrm{a}$ & $28.6 \mathrm{c}$ & $26.2 \mathrm{~d}$ & $25.7 \mathrm{~d}$ & $27.2 \mathrm{a}$ & $27.2 \mathrm{a}$ & $26.0 \mathrm{~b}$ & $23.9 \mathrm{~d}$ & $24.8 \mathrm{c}$ & $26.9 \mathrm{a}$ & $26.4 \mathrm{a}$ & $25.4 \mathrm{~b}$ & $24.2 \mathrm{c}$ & $23.6 \mathrm{c}$ & $27.0 \mathrm{a}$ & $26.9 \mathrm{a}$ & $25.8 \mathrm{~b}$ & $24.3 \mathrm{c}$ & $23.6 \mathrm{~d}$ \\
\hline Hue Angle & $178.9 \mathrm{a}$ & $178.9 \mathrm{a}$ & $179.1 \mathrm{a}$ & $178.9 \mathrm{a}$ & $178.6 b$ & $178.9 \mathrm{~b}$ & $178.9 \mathrm{a}$ & $178.9 \mathrm{~b}$ & $178.9 \mathrm{~b}$ & $178.6 \mathrm{~d}$ & $178.9 \mathrm{a}$ & $178.9 \mathrm{a}$ & $178.9 \mathrm{a}$ & $178.8 \mathrm{~b}$ & $178.5 \mathrm{c}$ & $178.9 \mathrm{~b}$ & $178.9 \mathrm{a}$ & $178.9 \mathrm{ab}$ & $178.9 \mathrm{c}$ & $178.6 \mathrm{~d}$ \\
\hline Browning Index (BI) & $48.2 \mathrm{bc}$ & $46.1 \mathrm{~b}$ & $49.2 \mathrm{~b}$ & $42.4 \mathrm{c}$ & $67.2 \mathrm{a}$ & $41.7 \mathrm{~b}$ & $37.9 \mathrm{~d}$ & $38.2 \mathrm{c}$ & $35.8 \mathrm{~d}$ & $65.3 \mathrm{a}$ & $43.7 \mathrm{~b}$ & $39.8 \mathrm{c}$ & $39.4 \mathrm{c}$ & $45.9 \mathrm{~b}$ & $67.1 \mathrm{a}$ & $40.7 \mathrm{a}$ & $36.6 \mathrm{ab}$ & $37.7 \mathrm{~b}$ & $36.5 \mathrm{~b}$ & $61.4 \mathrm{a}$ \\
\hline
\end{tabular}

${ }^{*}$ C: Control; FR: Freezer, RF: Refrigerator, R: Room temperature, ET: Elevated temperature. a, b, c, d, e denote significantly different color values (at 0.05 probability level) between control samples, samples stored in freezer, in refrigerator, at room temperature and at elevated temperature. ${ }^{\text {a }}$ Samples stored in freezer were packaged in glass bottles with plastic screw caps. ${ }^{b}$ samples stored in refrigerator, at room temperature, and at elevated temperature were packaged in aluminum foil laminate packages. 